\title{
Dikkat Ekonomisi Aracılığıyla Sosyal Medyayı Yeniden Düşünmek
}

\author{
Nilgün Tutal \\ Prof. Dr. \\ Galatasaray Üniveristesi Illetişim Fakültesi \\ Radyo Televizyon Anabilim Dalı Başkanı \\ ntutal@gsu.edu.tr \\ ORCID: 0000-0002-1535-7278
}

Yiğitalp Ertem

Bilgisayar Mühendisi yalpertem@gmail.com

\section{Abstract \\ Rethinking Social Media Through the Conceptualization- of the Attention Economy}

The accelerated renewal and widespread use of new communication technologies have brought up the question of attention, which focuses on the time spent with the media and the content produced or consumed in the media, as an important issue in the field of communication studies. The attention of those, who use new media or social media platforms to consume content or actually produce an "advantage" with the content they consume, has become the most important economic value of the postmodern or digital age. This article, in the light of theoretical debates, will discuss what the new structuring of the means of communication has transformed the attention of media users into, and will lay out, based on the intellectual sources of the discussions in question, what types of intellectual expansions it has provided for the phenomenon of new media and attention.

Keywords: Attention economy, social media, new media, technology 


\section{Résumé}

\section{Répenser les médias sociaux à travers la conceptualisation de l'écon- omie d'attention}

Le renouvellement accéléré et l'utilisation généralisée des nouvelles technologies de la communication ont amené la question de l'attention sur le temps passé avec les médias et le contenu produit ou consommé dans les médias comme une question importante dans le domaine des études de communication. L'attention de ceux qui utilisent les nouveaux médias ou les plateformes de médias sociaux pour consommer du contenu ou produire réellement un "avantage" avec le contenu qu'ils consomment est devenue la valeur économique la plus importante de l'ère postmoderne ou numérique. Dans cet article, on essaira de voir comment la nouvelle structuration des moyens de communication a transformé l'attention des utilisateurs des médias et quels types d'explications intellectuelles sont apportées, sà la lumiere du concept de d'économie d'attention traité par les differentes sources intellectuelles, dans les recherches en communication au phénomène des nouveaux médias.

Mots-clés : Economie d'attention, médias sociaux, nouveaux médias, technologie

\section{Öz}

Yeni iletişim teknolojilerinin hızlanan yenilenmesi ve yaygınlaşan kullanımı medya ile geçirilen zamana ve medyada üretilen ya da tüketilen içeriğe yönelen dikkat sorunsalını iletişim çalışmaları alanında önemli bir konu olarak gündeme getirmiştir. Yeni medya ya da sosyal medya platformlarını içerik tüketmek ya da tükettiği içerikle aslında bir "fayda" üretmek için kullananların sarf ettiği dikkat, post-modern ya da dijital çă̆ın en kayda değer ekonomik değerine dönüşmüştür. Bu yazıda iletişim araçlarının yeni yapılanmasının medya kullanıcılarının dikkatini günümüzde neye dönüştürdüğü kuramsal tartışmalar ışığında ele alınacak, söz konusu tartışmaların düşünsel kaynaklarına dayanarak yeni medya ve dikkat olgusuna ne tür düşünsel açılımlar getirebildiği serimlenecektir.

Anahtar Kelimeler Dikkat ekonomisi, sosyal medya, yeni medya, teknoloji 


\section{Giriş}

Internet teknolojisinin keşfedilmesi ve sosyal medyanın yaygın kullanımı dikkati günümüzde öncesinden farklı bir "değer" haline getirmiştir. Bunun en temel nedeni tüketime dayalı kapitalizmin ya da endüstri sonrası çağın en fazla artı değer yarattığı sektörün enformasyon ve eğlence sektörü olmasıdır. Henüz daha internet teknolojisi ve yoğun kullanımına yol açacağı sosyal medya platformları gün yüzü görmeden, dikkat kavramına ilk Herbert Simon 1971 yılında değinmiştir. Simon dikkati, enformasyon yoğun bir dünyada, enformasyonun tükettiği bir şey olarak tanımlar; dikkatin asıl az bulunan ve nadir bir kaynak olduğunun altını çizer. Dikkat ancak 1990 'ı yıllarda medya ve iletişim çalışmaları alanında daha çok tartışımaya başlanır, dikkat ekonomisini konu alan farklı yazılar da bu tarihlerde kaleme alınır.

Bu yazılarda Herbert Simon'un dikkat tanımına sıkça atıf yapılmaktadır. Belirtmek gerekir ki pek çok atıf alan Simon'un dikkat konusundaki makalesinde yazar daha henüz kavramı dikkat ekonomisi şeklinde kullanmamıştır. Dikkat ekonomisi kavramını 1990'lı yıllarda Maurice Goldhaber bir konferansta kullanır. Bu haliyle kavramdan başta internet olmak üzere dijital teknolojilerin yayılması ve buna bağlı olarak yeni iş ve gelir modellerinin doğması, tüketim alışkanlıklarının yerleşikleşmesi bağlamında daha çok söz edilmeye başlanacaktır.

Nitekim piyasa da dikkat ekonomisini içinde stratejiler geliştirilecek bir alan olarak görmeye başlayacak; eleştirel sosyal teori de bu yeni gelişen ve önemi kayda değer görülen olgunun ekonomik, toplumsal, kültürel ve psikolojik yönleri üzerine düşünmeye başlayacaktır. Sosyal teorideki bu tartışmalar, medya ve iletişim çalışmalarında 2000'li yıllardan itibaren mistikleştirilen teknolojinin her derde deva olduğuna dair savların felsefi terimlerle tartışımasına aracı olacaklardır. Bu yazıda teknolojinin sağladığı imkanlar felsefi, ekonomik, estetik ve sosyolojik alanların katkılarıyla tartışıldığında ortaya çıkan kavramsal manzaranın nasıl biçimlendiği ele alınacaktır.

Sosyal bilimlerde dikkat ekonomisini konu alan çalışmalarda, ücretsiz ve duygulanımsal emek üzerine yapılan araştırmalar hem nicel anlamda artmış hem de çağımızın yeni ekonomik ve politik renginin ne olduğu sorusu teknolojinin yaygınlaşan kullanımıyla yeni perspektiflerden tartışımaya başlanmıştır. Daha çok otonomcu Marksistlerin bu konudaki çalışmalarında, çağımızın yeni emek biçimlerinin ele alındığı açıkça görülmektedir. Bu çalışmalar kaynağını Marx'ın Grundrisse yapıtı ile Dallas Smythe'ın 1970'li yıllarda iletişim alanında gündeme getirdiği izleyici metası/emeği hakkındaki tartışmasına yaslanmaktadır. Bu tartışmalarda dikkat ve duygulanımsal emek altı çizilen önemli olgular olarak karşımıza çıkmaktadır.

Dikkat olgusu tartışmalarda hem meta hem de sermaye olarak nitelenmektedir. Medyada yer alan bir ünlü için kendine çekebileceği dikkat miktarı onun 
dikkat sermayesi olarak tanımlanırken, piyasa koşullarına göre dikkat, ekonomik sermaye olarak düşünülmektedir. Tüketen tarafındaysa dikkatin metalaşması söz konusudur. Ama bir yandan dikkat "kısıtlı bir kaynak" olarak tanımlandığında, tüketicinin harcayacağı dikkat miktarı da sermaye olarak düşünülebilmektedir.

Duygulanımsal emekse (affective labor) Michael Hardt ve Antonio Negri'den esinlenen İtalyan otonomcu yazarlarda sıkça ele alınan bir kavramdır; George Franck ise "bilişsel kapitalizm" kavramını tercih etmektedir. Jonathan Crary ve Dominic Pettman ile Tiziana Terranova dikkatin kuşatılması yüzünden, dikkat pratiklerinin bugünden kestirilmesi güç olan bilişsel ve duygusal etkilerinin altını çizmektedir.

Bu yazarlara göre sadece günlük hayatımıza, boş zamanımıza ait olan zamanımızı ve dikkatimizi satıyor değilizdir, bundan daha fazla olarak yeni iletişim biçimleriyle örgütlenen toplumsal düzenlemenin psikolojik halimiz, toplumsal ilişkilerimiz ve siyasallaşmamız üzerinde hasarlı etkileri söz konusudur. Ücretsiz emek, dijital emek, duygulanımsal emek, dikkat emeği gibi kavramların gördüğü işlev karşısında şöyle bir soru da sorulmayı hak etmektedir: Acaba bu yeni kavramsal araçlar, akademik bir üretimin motoru olma işlevini de üstlenmemekte midir? Dikkat ekonomisi tartışmaları bu şekilde değerlendirebilir mi? Dikkat ekonomisi bağlamında yapılan tartışmalar, temelde daha önceki emek ve yeni medya üzerine yazılan yazılara referanslarla ilerlemektedir. Yeni medyanın "yeniliği" tartışma konusuyken, dikkat ekonomisi tartışmaları da bazı anlarda dikkat ekonomisi kavramının meşruiyetini bu açıdan sorgulanır kılmaktadır.

Bundan ötürü pratik örnekler üzerinden düşünmeye çalıştığımızda, şu saptamaları yapmak kaçınılmaz olmaktadır: Dominic Pettman'ın Henri Lefebvre'e dayanarak söylediği gibi gündelik hayatın en önemli özelliği dolayımsızlığıdır. İki örneği düşünelim: Birinde, bir iş ortamında birlikte çalıştığımız kişiyle geçirdiğimiz emek zamanının dışında, boş zamanda (leisure) buluşup sohbet edebiliriz. Diğerindeyse yine aynı boş zamanda bir sosyal medya şirketinin platformunda konuşmayı tercih edebiliriz. İlki iletişim teknolojisinin dolayımıyla gerçekleşmezken, bundan farklı olarak ikincisinde bir şirket, iletişimin altyapısını bize sunarak (kullanım değeri) konuşmalarımızda biriken veriden ve bu verinin işlenmesinden, bu sayede aldığı reklamlardan bir kâr sağlamaktadır. Bunu daha genele yayınca geleneksel anlamda emek dışı vaktin de sürekli olarak şirketlerin dolayımına maruz kaldığını açıkça görmekteyiz.

Dikkat ekonomisi tartışmalarını konu alan metinlerde, kendisine hiç gönderme yapılmayan bir düşünür Louis Althusser'dir; Söz konusu dikkat ekonomisi tartışmalarını Louis Althusser'in emeğin yeniden üretimi kavramıyla da düşünebiliriz. Konuya bu açıdan bakınca, bir süreklilikten söz etmek olası hale gelmektedir, geçmişe göre değişen çok fazla bir şey aslında yoktur. Sadece emeğin yeniden üretiminin nasıl gerçekleştiğine dair detaylar bulunmaktadır karşımızda. 
Bu aşamada bir başka soru da kendini dayatmaktadır: Dikkat ekonomisinde satılan/metalaşan nedir? Zaman mı, dikkat mi yoksa veri mi? Zaman ve dikkat arasındaki ayrımı nasıl yapabiliriz?

Öncelikle şunu belirtmekte fayda var: Dikkat ekonomisinin daha ekonomik terimlerle tartışılması durumunda, Marksist literatürün emek ve değer tartışmaları ile kapitalizmin finans kapitalizmine dönüşmüş olması gibi olguların emeğin yeniden üretimi bağlamında yeniden tartışıldığını görmekteyiz. Ayrıca başka bir tartışma katmanında ise, dikkat ekonomisinin insan beyninin ve zihninin işleyişine, sosyalleşmeye ve siyallaşmaya etkileri, kişinin ruhsal durumuna etkileri gibi sorgulamalarda da psikoloji, sinirbilim, sosyoloji ve siyaset bilimine dair disiplinlerarası tartışmalar gündeme gelmektedir.

Bu açıdan bakıldığında, dikkat ekonomisi hakkındaki tartışmaların disiplinler arası okuma ve bilgi gereksinimini kamçıladığını, medya ve iletişim çalışmalarına zengin bir araştırma ve kuram kapısı açacak bir zenginliğe sahip olduğu da görülmektedir. işte bu makalede yeni iletişim teknolojileri ve sosyal medya ortamında dikkat ekonomisi literatürü aktarılacak; ilgili yazında referans olan düşünürlerin konuyu ele aldığı kavramlar betimlenecek, tartışılacak ve aralarında bağlantılar kurulacaktır.

\section{Geç Kapitalizm ve Uykusuzluk}

Uyku zamanının hız, hareket ve verimlilik buyruğu ile çelişen bir yapısı olduğu açıkça ortadadır. Jean Baudrillard'ın seyahat deneyimini kaleme aldığı Amerika'da Amerikalıların en çok yoksun olduğu şeyin uyku olduğunu sosyal medya kullanımı henüz daha bu kadar yaygınlaşmamışken yazdığını biliyoruz. Artık uyku ile geç kapitalizmin ilişkisi çok daha çetrefilli bir yola girmiştir. Eğer ekonominin en önemli girdisi ya da hammaddesi insanın zamanı ve dikkati haline gelmiş ise, araçsal rasyonaliteyi içerdiği mantığın sonuna iten çağımızda uykuyu yenmenin yolları, insanı uykudan "özgürleştirmenin" çareleri bilimsel araştırmaların öncelikli alanı haline gelmiştir.

Jonathan Crary (2015), uykusuzluğun bir ihtiyaç olmasının önüne nasıl geçileceğine dair yapılan araştırmaların ilk olarak askerlerin uyku sorununu halletmek üzere başladığına işaret eder ve artık üretken ve verimli kılınması gereken her insan için bu araştırmaların uyku ihtiyacını ortadan kaldıracak çareler aradığını belirtir. Yazar, ilaç sektörünün bu iş için çoktan çalışmaya başladığını ve uykusuzluğu bir yaşam tarzı olarak pazarlamaya hazırlandığını haber veriyor. Uykuyu sorun olarak gören bu akıl yürütüş, ilk Amerika Birleşik Devletleri'nde uykusuzluk ile itaat arasında güçlü bir bağ olduğu tanısından haretkle, Guantanamo'da mahkumları itaatkar kılmak amacıyla yararlanmıştır; dolayısıyla aslında bir işkence tipinin toplumsal uzvun bütününe yayılmasıyla karşı kaşıyayız.

Crary'nin dikkat ekonomisi konusundaki bu gözlemi en sert saptamalardan birini oluşturur. Dijital tüketim alanında işleyen ağ mantığının kökeninde devletin 
işleyişi ve askeri-endüstriyel tahakküm pratiklerinin (Irak, Afganistan ve Guantanamo örnekleri) bulunduğuna işaret etmiştir. Taylorizm iş bilgisi elinden bilimsel yönetimle alınan çalışanın daha hızı ve daha kolay manipüle edilebilir: daha az ücrete daha çok iş yapan bir montaj hattı işçisine dönüşmesinin yolunu açmıştı. Fordizm ile zirvesine ulaşan bu bilimsel yönetim pratiği şimdi tüketimci ve finansal kapitalizm çağının iş yapılanmasının adı olan post-fordist düzende hem çalışanı hem de tüketiciyi uykusundan bile etme yoluna girmiş görünüyor. Politik ve ekonomik iktidar, dikkatin ve uykunun kendi hanelerine girdi olarak yazılması arayışında, tahahakküm meyillerini günlük yaşamında sıradan insana musallat etmiştir artık.

“Uyku yoksunluğu insanı aşırı bir âcizlik ve itaate sürükler ... uykunun esirgenmesi bir dış kuvvetin benliğe el koyması, bireyin ayrıntılı olarak hesaplanmış biçimde paramparça edilmesidir." (Crary, 2015, s.18)

Bu saptama öznenin bio-iktidar teknik ve stratejileriyle biyolojik varlığına indirgenmesi konusunda çağımızın geldiği son aşamayı radikal bir şekilde görülür kılmaktadır. İnsanın nüfus kütüğündeki nicel bir varlık olarak düşünülmesinin en uç noktası demek ki; yaşamın doğal ritminin kurucusu olan uykunun reddedilmesi şeklini alarak, somut bir iktidar pratiğine dönüşmektedir. Bu bağlamda Jonathan Crary insanın 24 ssat boyunca işlemesi ve çalışması gereken bir makine olarak tasavvur edilmesi arayışından bahsederek, çalışma ve emeğin artık kesintisiz faaliyetler olarak koyutlandığının altını özellikle çizmektedir.

Uyku araçsal ve fizyolojik bir deneyim olarak kodlanırken, insan ile makine arasındaki bağ da insana yönelik bir uyku modunun oluşturulması şeklinde dönüşüm geçirmektedir. Uyku, bir makine işlevi olarak tanımlandığında bir makinenin az enerji tüketimi modunda gelen sinyalleri her an almasına benzer bir fonksiyon insana da eklenmektedir. Bu konuda yapılan araştırmalara atıfla Jonathan Crary, gece uyurken gelen mesajlarını kontrol etmek için uyanan insan sayısının hızla arttığını belirtmektedir.

Giorgio Agamben bu durumu İstisna Hali'nde: İnsan bu durumda makine gibi işlemesi gereken, ancak makine de olmadığı için, yani canlı emek olduğu için emeğinin ve zamanının değeri kesintisiz bir şekilde araçsal bir üretkenlik mantığına göre kontrol altına alınması gereken bir bios olmaktadır. Bu düzende ayrıca canlı emeğin değeri de düşüşe geçmektedir, insanın dinlenmesi ve sağlıklı olması piyasa toplumunun öncelikli amacı hiç olmamıștı, ama bugün insan yine Agamben'in Kutsal İnsan'da özenle altını çizdiği şekilde gözden çıkarılan bir varlığa dönüşmüştür. Üstelik çağımız insanına çalışma, tüketime ve pazarlama zamanından geriye dinlenmek için zaten çok bir zaman da kalmamaktadır. Bu tanıyı Crary (2015, s. 25) Luc Boltanski ve Eve Chiapello'dan almaktadır:

"Luc Boltanski ve Eve Chiapello çağdaş kapitalizm tahlillerinde telematik ortamda sürekli meşgul, temas halinde, etkileşim içinde olan, iletişim kuran, tepki veren ya da işleyen bireyi takdir eden bir 
dizi kuvvete işaret ederler. Dünyanın refah içindeki kesimlerinde, bu durumun özel zaman ile mesleki zaman, çalışma zamanı ile tüketim zamanı arasındaki sınır çizgilerinin çoğunun erimesiyle meydana geldiğini kaydediyorlar."

Demek ki 7/24 zamansallığı gerektiren, her an bir şey yapıyor olma ihtiyacı topluma yayılmakta, boş durmaya hiç zaman kalmamaktadır. Bu da insanın duyusal yetilerini yitirmesini, hafızasının zayıflamasını, deneyimlerinin farkirleşmesini beraberinde getirmektedir. Daimi erişim, yaşamın periyodikliğini ortadan kaldırmaktadır.

Oysa uyku kapitalizmin hiç durmadan işleme ve üretken olma mantığına karşı insanın direnebileceği insani tek gereksinimdir. Uykuda geçen zaman kapitalizmin üretme ve tüketme buyruğuna direnilebilecek tek zamandır. Tıpkı Tüketim Toplumu kitabında Jean Baudrillard'ın yıllar öncesinden, daha 1970'li yıllarda işaret ettiği, azalan ve nadir hale gelen, kıt olanın bolluk söyleniyle mitikleştirilmesi artık uyku için de söz konusudur. Demek istediğimiz doğal kaynakların azalması bir doğal/doğallık nitelemesinin piyasada satılan tüm metaların ayırdedici özelliği kılnmasıyla örtülmekteydi. Benzer şekilde yok edilmeye çalışılan uyku zamanı da zamanın bollaştırılması zorunluluğuyla kıt bir şeye dönüştülmesinin bir biçimidir. Daha çalışkan, daha üretken olmak için, daha fazla maddi gelir elde etmek için boşa geçirildiği var sayılan uyku zamanını azaltmak, böylece araçsal üretim ve tüketim mantığına hizmet eden kıt olduğu var sayılan zamanı artırmak bir zorunluluk olarak önümüze koyulmaktadır.

Bu durum, çalışma ile boş zaman ayrımının yok olmasıyla imgelerle geçirilen zamanın artııımasının zamanımızın egemen bir buyruğu olduğunu görünür kılmaktadır. Bunun anlamı ise çağımızın egemen işleyişinin daha da pekiştirilmesi demektir. Bernard Stiegler'in "kitlesel senkronizasyon" kavramı, 1990'ların ortasından itibaren internetin yaygınlaşmasının insanın deneyim alanlarında öznelliğin ve tikelliğin var olma şansının insanın elinden alınması demek olduğunu söylemişti. Bunun içindir ki Bernard Stiegler yaratıcılığın ve katılımın bir an önce yeniden ortak yaşam arzusuyla canlandırılması gerektiğini ısrarla savunmuştur diyen Crary Stiegler'in, "arzuyu bir şekilde tüketim buyruklarından koparabilecek karşı ürünlerin yaratııması için acil bir çağıı" yaptığını yazar. (Crary, s. 57)

Jonathan Crary buraya kadar aktardığımız kavramsal evreninde Luc Boltansky; Raymond Williams ve Bernard Stiegler gibi sosyolog ve felsefecilerin düşüncelerinden feyz alarak dikkat ekonomisi tartışmalarına ışık tutmaktadır. Jonathan Crary'yi ele aldığımız konu açııından ilginç kılan, kendi kavramsal evreninden daha çok, böyle dışarıdan transfer ettiği kavramlarla iletişim alanında "yeni" tartışılmaya başlayan dikkat ekonomisi olgusunu zenginleştirmesidir. Bunu Jonathan Crary'nin örneğin "yeni dijital çağ" ekseninde çalışmaları olanları, "sahte entelektüeller" olarak nitelemesinde de açıkça görmekteyiz. Raymond Williams ve Bernard Stiegler'in kültür sosyolojisinden temellenen Crary'nin bakış açısı tekonolojinin imkanlarını olduğu gibi alıp teknoloji övgüsü yapanlardan farklılaşmaktadır; 
teknolojideki hızlanan dönüşümlerle, toplumun teknolojiyle ilişkisinin günümüzde sürekli değişmesi yüzünden teknolojiyi bireysel açıdan yakalamanın gittikçe daha da zorlaştığına; bunun da bireyler üstünde yadırgatıcı ve güçsüzleştirici bir etkisi olduğuna işaret etmektedir. Örneğin, yeni medya üzerine beş yıl önce yazılan kitap ve makalelerin çoğu şimdiden hükmünü yitirmiştir.

Crary, yeni iletişim araçlarının özgürleştiriciliğine dair övgüler almış başını giderken, asıl bu övgülerde gözden kaçırılanın, sanallık ve cisimsizleşmenin insan emeğinin bir uyku modu halinde her an tüketilmeye hazır olarak bekletilmesinin emek üzerinde neden olduğu baskı ile kapitalizmin doğayı onulmaz bir biçimde tahrip etmesi arasında derin bir bağ olduğudur. Dikkat ekonomisini bu bağlamda Crary iletişim alanında genel geçer önyargılardan arınmış olarak eleştirel bir bakış açısından değerlendirebilmektedir: Aynı şekilde iletişim araştırmalarında çok da altı çizilmeyen dikkatin yeniden üretiminin kültür ürünlerinin türdeşlemesinden ve bu türdeşleşmenin yarattığı insani ve toplumsal arazlardan çok daha tehlikeli bir durum arz ettiğini de Crary'den okuyabiliyoruz:

“Bugün en önemli mesele...dikkatin bakma ya da dinleme edimleriyle daima örtüşen mükerrer işlem ve tepkiler halinde yeniden yaratılmasıdır. Bireylerin ayrılmasını, tecridini ve nötrleştirilmesini daimi kılan şey, medya ürünlerinin homojenliğinden ziyade, bunların ve daha pek çok unsurun tüketildiği, daha kapsamlı ve zorunlu düzenlemelerdir." (2015, s. 58)

Çalışma ve boş zaman arasındaki ayrımın ortadan kalkması, bireyler üzerinde özel yaşamda tıpkı iş yerinde olduğu gibi bir rekabet hırsı yaratmaktadır. Bunu yapmak içinse insan yine teknolojik kaynaklardan yararlanma becerisi geliştirmeye çalışmaktadır. En mahrem olan yerde bile egemen kodlar ve klişeler insan yaşamını abluka altına almaktadır.

Crary dikkat ekonomisini konu alan diğer makalelerde de sıkça karşılaştığımı Gilles Deleuze'ün "Postscript on the Societies of Control" (1992) makalesinden ve Guy Débord'un Gösteri Toplumu (1988) kitabından da yararlanır. Bu iki metnin o dönem pek yakalanamayan dönüşümü farklı şekillerde işaretlediğinin altını çizerken, eleştirel bir şekilde Gilles Deleuze'ün disiplin toplumundan denetim toplumuna geçiş tartışmalarını ve Guy Debord'un yirmi yı önce yazdığı Gösteri Toplumu'nda gündelik hayata dair söylediklerinin genişlemesine dair tespitler yapar. 1990'ların başında, tıpkı 19. yüzyılın. sonlarında ulaşım ve iletişim ağlarının genişlemesine benzer bir dönüşümün yaşanmakta olduğuna işaret eder.

Crary (2015) 1950'lerde evlerde televizyonun yaygınlaşmasını, "pazarların da önceleri ilhak edilmemiş zamanlar ve alanları temellükünde başka bir dönüm noktası" (s. 82) olarak değerlendirmektedir. Dikkat ekonomisi üzerine düşünürken bütün bu yeni iletişim teknolojilerinin hangi açılardan televizyondan farklı olduğu sorusu mecburen akla gelmektedir. Çok daha büyük bir dalga olması açısından daha kapsamlı fakat benzer tartışmalar yıllar öncesinden televizyon hakkında 
da yapılmıştır. Yeni iletişim teknolojilerinde niceliksel olarak daha hassaslaştırılan müşteri ölçme yöntemleri, özel alanın temellükü televizyon için de söz konusuydu. Crary de bu paralelliklerden söz eder: "Yüz milyonlarca birey birdenbire her gün her gece bilmem kaç saatini az çok hareketsiz biçimde, kırpışıp ışık yayan nesnelerin dibinde geçirmeye başladı." (s. 83)

Buradaki alıntıda televizyondan yeni iletişim araçlarına geçişin, zamanı ve uzamı kuşatmada bir ileri adım olarak değerlendirildiğini düşünebiliriz. Web 2.0 teknolojisiyle yeni iletişim ortamındaki etkileşimi olumlayan, 1990'ların küreselleşme övgülerinde filizlenen söylemin eleştirisi ve dikkatin temellüküne dair yeni pratikleri yücelten iddilara karşı Crary, etkileşimin bir düş olduğunu, demokratik ve hiyerarşik olmayan bir toplum beklentisinin de boşa çıktığını öne sürer. Sosyal medyada kimliğini kurmaya çalışmak zorunda kalmanın eleştirisi olarak okuduğumuz bölümde de Crary kişilerin cansız kimliklere büründüğünün, sahte bir kurtuşulun peşinde yorgun düştüklerinin altını Raymond Williams'tan yararlanarak saptamaktadır. (bkz, Crary, s.104).

\section{Günlük Yaşamda Dikkat Dağınıklığı}

Jonathan Crary'nin kültürel yaklaşımının aksine Dominic Pettman daha çok ekonomi-politik bir yaklaşımı benimser. Sosyal medyayı sınırsız ve sınırlanmış bir etkileşim alanı olarak görmektedir. Sınırsızlığı, herkesin kendine özgü bambaşka deneyimlere sahip olabilmesinden, sınırlanmışlığı da deneyimin eninde sonunda ekonomik iktidarı elinde bulunduranlarca belirlenmesinden dolayı gündeme getirmektedir. Pettman sosyal medyanın incelikle ayarlanmış bir düzenek olarak dikkatimizi bir endüstrinin hizmetine sunduğuna işaret eder:

"Sayısız şirketin markalaştırmaya çalıştığı anlamıyla 'sosyal medya'nın eleştirisinden söz etmek daha doğru olur. Yani, odağımızı daraltmak, dikkatimizi devamlı şekilde verme kabiliyetimizi ketlemek ve aramızdan mümkün olduğunca çok kişiyi dizginsiz tüketimin etkileşimli sahasına gütmek için incelikle ayarlanmış mekanizmalardan müteşekkil, sahne dışındaki koca bir endüstriye işaret eden dar, basit anlamıyla sosyal medya." (2017, s. 11 vd)

İnsanın kendine ait -olduğunu düşündügü- alışkanlıklarının günden güne algoritmalarla ve veri analizleriyle daha çok belirlendiğini öne sürer. Şirketler, insanı internette bıraktığı izler üzerinden yeniden tanımlamaktadır. İnsan, yurttaş olmakla tüketici olmak arasında gidip gelmektedir. Pettman bu insanı konu edinirken, diğer makalelerde de anıldığı üzere Deleuze'ün "bölünmüşlük" (dividual) kavramına başvurarak, insanı "modüler bir ontolojinin alt-öznesi" (2017, s.16) olarak tanımlar.

Pettman yine de tekno-pesimizmden kaçınma taraftarıdır. Her teknolojinin yeni bir Marshall McLuhan, Alvin Toffler, Neil Postman, Sherry Turkle gibi düşünmeyi uyaran yazarlar yaratmış olmasını önemser. Jean Baudrillard'a bu eleştirel yazarlar arasında ayrı bri önem atfeder. Frankfurt Okulu hattında ilerle- 
se de Baudrillard "bu kuraldışı gelişmelerden yakınmadığını, zira açıklama getirmek için henüz çok büyük ve hızlı olduklarını yeri gelince ısrarla belirtmiştir" der. (2017, s. 17 vd). Jean Baudrillard'ın İetişim Esrikliği'nde "narsisistik ve çok yönlü bağlantı çağı" ve "kişiye özel 'telematik'" gibi tanılarından hareketle günümüz dijital teknolojilerinin çözümlemesini yapar. Böylece Pettman, günümüz iletişim teknolojilerini hem aramıza mesafe koyarak kendi alanımızdan başkalarını uzak tutma hem de istediğimizde bir tıkla onlara ulaşabilme yakınlığı sunan devasa bir altyapı olarak betimler.

Pettman'a göre, günümüzde iletişim teknolojileri ciddi bir dikkat dağııımına ve oylanmaya yol açmakta; odak noktası çok rahat kaybedilebilmektedir.

"Daha ziyade tuzağın kendisi, -yani, dikkat dağıtmak için tasarlanmış şey- dikkat dağılmasına yönelik zorunlulukla birleşmiştir ... Olayların devamlı ve bilinç olarak şekillendirilmiş temsillerinin ta kendisi yine o olayları örtmek ve susturmak için kullanılmaktadır." (2017, s. 21)

Baudrillard'ın kitlelerin sessiz çoğunluğa dönüştüğü argümanına dayanarak; kitlenin atalet ve nötrlük özelliklerine Pettman da dikkati çeker: Baudrillard'ın bahsettiği televizyon seyircisiydi, ancak televizyon seyircisini çağımızın yeni iletişim aygıtları kadar yakından takip etme gücüne hiç sahip olamamıştır; kişiler kendilerine ait bilgileri müthiş bir hızla ortalığa dökmekte yarış içindeler ve bundan ötürü de "benlikler" metalaşmaktadır. Yeni iletişim teknolojileri bağlamında Pettman "... kısa süre önce oluşmuş yapısal koşullardan biri de, çevrimiçi/çevrimdışı ayrımının kesinkes yitmiş olmasıdır ki, bu da artık sanal ile gerçeği rahat bir şekilde zıtlık içerisinde göremeyeceğimiz anlamına gelir." (2017, s. 23 vd) değerlendirmesini yapar.

Frankfurt Okulu ve çevresinin dikkat dağılmasına dair yaklaşımlarından yararlanan Pettman, Siegfried Kracauer'in sinema salonunun homojenleştirici etkisine, Walter Benjamin ve Siegfried Kracauer'in karelerin hızla aktığı sinemanın estetik algılama ve derin düşünme üzerindeki tahrif edici etkisine özellikle vurgu yapmaktadır.

Benjamin'in “Tekniğin Olanaklarıyla Yeniden Üretilebildiği Çağda Sanat Yapıtı"ndan esinlenerek şöyle yazar :"Dikkat dağılması ile yoğunlaşmanın oluşturduğu karşıtık, şu şekilde formüle edilebilir: Sanat eseri karşısında dikkatini toplayıp yoğunlaşan kişi, bu eserin içine gömülür... Dikkati dağılmış kitlelerse sanat eserini kendi içine dahil eder." (2017, s.29)

Benjamin'in dikkat dağınıklığıyla ilk ilişkilendirdiği sanat deneyimi olan mimariyi günümüze taşıdığında Pettman, fizyolojik bir olgu olarak mimariyi, günümüz dijital ortamının mimarisiyle eşleştirmektedir.

Crary gibi Pettman da Bernard Stiegler'in kavramlarından yararlanmaktadır. Örneğin Stiegler'in 'hipersenkronizasyon' kavramına atıfla, bu kavramla Stieg- 
ler'in halk denilen politik uzvun halk olarak inşa edilmesinin kolektif olanı tekonolojinin kullanım biçiminden dolayı yok ettiğinin altını çizer:

"'(H)ipersenkronizasyon; fizyolojik ve fantazmatik mekanizlamar aracılığıyla, dikkatin, davranışın ve düşüncenin kurumsal şirketdevlet eliyle sinik bir şekilde kontrol altında tutulmasıyla ilgilidir." (Akt. Pettman, 2017, s. 32)

Pettman Stiegler'in hipersenkronizasyon kavramına sosyal medya bağlamında bir alternatif de önermektedir. Sosyal ağlara senkronize olmaktan çok, bu ağların yarattığı bir modülasyonun nesnesi olabilir miyiz? Aynı şeye senkron olmak yerine "olası müttefiklerimiz ve akranlarımızla asla aynı şekilde hissetmememize neden olacak şekilde" niyet etme olabilir mi? "Kasti uyumsuzluk", "verimli gecikme", "yalpalayan oyalanma" gibi kavramsal araçları da bu bağlamda önermektedir. Pettman'ın önerdiği kavramlara biraz yakından değinmek, yazarın düşünsel yolculuğunu daha iyi kavramamızı sağlar.

Hipermodülasyon Pettman'da olayların mutlak biçimde birbiriyle değişebilir hale gelişine istinaden kullanılmaktadır. Bilgilenmek bu durumda oyalanmaya dönüşmüştür. Bu da ortaya bilişsel bir uysumsuzluk (s.36), yani var olmak için gereken zaman ile bu bigilenme/oyalanmanın zamanın birbiriyle çelişik olması söz konusudur. Gününümüz sosyal ağları birkaç kişinin planlayıp uygulamaya soktuğuna dair komplocu eleştirilere katılmayan Pettman, sosyal medyayı: "para kazanma dürtüsünün Tanrı rolünü üstlendiği, usta işi "akıllı bir tasarım' örneği" (2017, s. 39) olarak okumaktadır. Hipersenkronizasyon ve yeni sembolik sosyal çevrelerin bireydeki olumsuz etkilerini yine Stiegler'e atıfla dile getirir. Bu olgu libido kaybına, yaşam enerjisinin tükenmesine, benliğin de bu nedenle düş kırıklıklarıyla yaşamaya mahkum olmasına yol açmaktadır. Duygular yok olmuştur, birlikte olmanın daha eski biçimleri de bu duygu yoksunluğu çağında bir bir yıkılmıştır $(2017$, s.41)

Pettman bu bağlamı biraz daha kavramsal olarak çözümlemek için Giorgio Agamben'e baş vurur. Pettman, Agamben'in teknoloji ve aygıt eleştirisi üzerine yazdıklarına atıfla, mevcut yaşamın beşeri özgürlüklerle birlikte kendi yaşamlarımızın öznesi olmaktan da mahrum edilmesiyle işlediğine işaret etmektedir.

Pettman'ın önemsediği bir diğer kavram da Tom Standage'dan aldığı senkronizasyondur. Pettman insanlığın daima dünya ile senkron olma ihtiyacından söz ederek, örneklerini tarihselleştirmektedir. Örneğin duvar yazılarından Viktorya dönemi telgraflarına, internette ve sosyal ağlarda süren biçimine kadar iletişimin insan toplumu kadar eski olduğunu söylemektedir. Dedikodunun kadimliğini bu duruma örnek olarak gösterir. Bir arabada giderken en sevdiğimiz şarkılarla doldurduğumuz kasetler yerine radyoyu açıp dinleme intiyacımıza istinaden bir "senkronizasyon istenci" kavramını önerir. İşte medyanın enerji kaynağı bu noktadır. Senkronizasyon istencini evrimsel (biyolojik), metafizik (toplumsal-manevi), duygulanımsal (fenomenolojik), tarihsel (teknik, biyopolitik) ve tarih-sonrası (libidinal-ekolojik) düzlemde değerlendirir (2017, s.53). 20. yüzyıl sonundan günümüze 
bu istencin yabancılaşmayla kuşatılığını öne sürer. Pettman'a göre deneyime ve mantığa dayanmayan yaşamların, sürekli daha fazlasını vaat eden gösterinin içinde yaşadığı bir yabancılaşma çağında yaşamaktayız.

Pettman 'Biz' denilen toplumsallığın yitirilmesine günlük yaşamın dolayımsızslığının yitirilmesinin neden olduğunu Henri Lefebvre'e dayanarak söylemektedir. Yine Lefebvre'in günlük hayattan bir parlama olarak okuduğu "moment" kavramını da böylesine medyayla dolayımlanan etkileşimler içinde bulmanın gittikçe zorlaştığının altını çizer ve (2017, s.70 vd) biyo-iktidar zor yoluyla değil severek kullanılan metalar üzerinden renkli ve eğlenceli bir hale gelmiştir diye yazar. Pettman böylece, her an her yerde ulaşılabilir olan içeriği, eğlence medyasının zamansal niteliğinin mekansal bir niteliğe dönüşmesi olarak okuyabilmektedir.

Pettman dikkat ve emek ilişkisi hakkında ise Marksist yaklaşımının emek ile dikkat arasında kurduğu bağın, söz konusu olan dikkatin kesintisiz yeniden inşa edilmesi zorunluluğunu kavramakta zayıf kaldığına işaret etmektedir :

"Marksist bakış açısına göre dikkat, emeğin okunduğu şekilde okunamaz. Çünkü iş bir şekilde yapıldığı müddetçe sermaye, emeği kimin sarf ettiğiyle pek alakadar olmaz. Ne var ki söz konusu dikkat olunca, "bu işleri takip edenler nezdinde, tık sayısı ve sitede geçirilen süre kadar kimin dikkat kesildiği de önem arz ettiği için, her tür soyutlama ve niceleme girişiminin gerektirdiği dikkat standartlaşmasını dayatmak zorlaşır." (2017, s. 76)

Sosyal medyanın gereksindiği sürekli yeniden üretilmesi gereken dikkat tipinin temel niteliğini ise Pettman Sigmund Freud'un Uygarlığın Huzursuzluğu'ndan yararlanarak açıklar. Bu yapıtında Freud bilincin yüküyle başa çıkmak için başvurduğumuz üç ana yoldan söz etmiştir: "Kuvvetli dikkat-dağıtıcılar", "ikame doyumlar" ve "sarhoş edici maddeler". (2017, s. 94 vd) Pettman'a göre, sosyal medyaya olan iştah, bulimik bir iştahtır.

Ne yapmak gerekir sorusuna karşı ise Pettman yine de umutlu bir cevap vermeye çalışır: Hakikatla karşı karşıya kaldığı için uyuştulmaya bu kadar kolay rıza gösteren kitleler bir vaad kaynağıdır da.

\section{Net'te Dikkatin Ekonomik Serüveni}

Maurice Goldhaber daha radikal bir ekonomi-politik yaklaşımla dikkat ekonomisini irdeler. 1997'de internetin artık zamanımızı geçirdiğimiz bir alan olduğuna göre, ekonomisinin çalışılması gerektiğini ilk söyleyen yazardır. Ekonomisi derken fiyatlar, maliyetler ve üretim ile ilgili tezleri dijital enformasyona uygulamamızı kastetmektedir.

Fiziksel mal üretiminden yepyeni bir döneme geçtiğimiz için, çağımızın yeni ekonomik terimlerle düşünülmesi gerektiğinin altını çizer. Bu bağlamda eski eko- 
nomik kavramların bir değeri olmayak mıdır? Fiziksel mal üretimi ve tüketiminden yeni bir tüketime mi geçilmiştir? Hizmet toplumu tartışmaları, post-endüstriyel toplum tezleriyle aslında net ekonomisinden önce yapılmaya başlanmamış mıdır?

Goldhaber'e göre yeni döneme yeni isimler verilmesi, yani enformasyon çağı, üçüncü dalga vb. kavramların kullanılması bizi yeni olana dair muğlak tanılarda bulunmaya itmektedir. Bunları çözmek için önerisi ise düşüncenin merkezine dikkat ekonomisini koymaktır. Değişimi ifade etmek için de iki analojiye başvurur.

Birincisi, dünyada organik bir yaşamın olmadığı yıllardan sonra bir yaşamın belirmesinin anlaşılmasına odaklanma önerisidir. Bu dönüşüm, fizik ve kimyanın kavramlarıyla açıklanamaz. Yeni yasalarla işleyen; internet ve siber alanla da böylesi yeni bir yaşam doğmuştur. Ekonomiyle analoji kurunca, elbette hiç olmayan bir şeyin ortaya çıktığını söyleyemeyiz ancak eskinin kurallarını yerinden edip yenilerini koyan yeni yasalar ortaya çıkmıştır, ama bu yeni yasaları yeni adlandırmalarla değil, ekonomideki dönüşümlere dair yeni bir yaklaşım ortaya koyarak kavrayabiliriz.

İkinci analoji ise, Amerika'nın keşfedildiği 15. yüzyılda keşifler sırasında Avrupa'daki feodal yönetim ve ekonomik düzen arasında kurulmaktadır. Kölelerin bu keşfedilen yeni 'alan'a (space) gönderilmesiyle kapitalist ekonominin temelleri atımıştır. Manzarasını küçük tarlalar, surlarla çevrili köyler ve kalelerin oluşturduğu feodal sistemin yerini endüstriyel kentler, bacası tüten fabrikalar, demiryolları, kanallar ve otobanlar almıştır. Siber alanın manzarası belki sadece zihinlerimizde mevcuttur, fakat bu alanla ilişkimizin geçmiş yüzyıllardan farklı olması da bu bağlamda çok doğal karşılanmalıdır. Milyarlarca insanı etkileşime sokan bu alanın yapısı elbette geçmişteki örneklerden farklı olmak zorundadır. Bu yeni dünyada başarıı olmak için bugünün dükleri ve pırlantalarını değil gelmekte olanın mantığını düşünmek gerekmektedir.

Işste bu iki analojiye dayanarak Goldhaber, yeni bir doğal ekonomi tasarısı önermektedir. Bu yeni ekonomi ne ile ilgilidir? Genelde herkes bunun enformasyon ile ilgili olduğunu söylemektedir, oysa Goldhaber'e göre bu imkansızdır. Ekonomiyi çeviren kısıtı/nadir kaynaklardır, internette ise enformasyondan bol bir şey yoktur. Bu durumda Goldhaber enformasyon bolluğunun tam karşıt ucunda konumlanan dikkatin merkeze alınması gerektiğini önemle vurgulamaktadır. 'Dikkat' doğası itibariyle kısıtıı bir kaynaktır.

Ayrıca dikkati mutlak anlamda arzulayanların yanı sıra kendisine yönelen fazla bir dikkatin peşinde olmayanlar da vardır. Fakat yine de dikkat, tıpkı hayatta kalmak için gerekli olan diğer fiziksel ihtiyaçlar (beslenme, barınma, bebek bezi vb.) gibi asgari miktarda ihtiyaç duyulan bir şeydir. Dikkat gösterilmediğinde bir bebek temel intiyaçlarını karşılayamaz. Çok utangaç ve münzevi bir bireyin bile asgari oranda dikkat gösterilmeye ihtiyacı vardır. Bunu en çok da kamusal şahsiyetlerin gereksindiği ya da arzuladığı dikkat söz konusu olduğunda fark etmekteyiz. 
Internette enformasyon bir yönde ilerlerken dikkatin de karşıt yönde ilerlemesi de söz konusudur. Ayrıca dolayımlanmış iletişimde dikkatin yanılsamalı bir şekilde var olduğunu da düşünmek kaçınılmazdır. Örneğin, konuşma yapan birisi ve dinleyenleri düşünelim, dikkatin eşit miktarda değiş tokuş edilmediği açıkça ortadadır. Asimetrik bir dikkat alışverişi söz konusudur, iki kişinin konuşmasından farklı bir durum vardır karşımızda. Çünkü konuşmacı dinleyenlere bir yanıltıcı dikkat sunmaktadır. Böylesi konuşmalar bir enformasyon iletimi gerçekleşeceği vaadiyle dinlenmektedir. Bu da dikkat değiş tokuşunu eşitler görünmektedir. Neden eşitlenmesi gerekiyor? Retorikçiler hep bu dikkatin peşinde koşmuşlardır. Dinleyiciler konuşmacının onlara verdiği dikkatin karşılığını vermediklerini düşünebilirler, ama aslında tam tersi olmaktadır. Konuşmacı dinleyicilerine dair hiçbir şey bilmez, fakat dinleyiciler konuşmacının yüzü, sesi ve düşüncelerini hatılladıkları kadarıyla bilirler.

İnsanların çeşitli kişilerin konuşacağı bir etkinliğe gelmesinin nedeni onu düzenleyen kişi olabilir. Ona şimdiye kadar epeyce dikkat göstermişlerdir. Bu sebeple orada konuşan diğer kişileri de dinlerler. Bu da dikkatin devredilebildiğini ve aktarılabildiğini göstermektedir. Konuşmacı birini seçip ona sözü verirse, dikkati başka bir alana aktarabilir. Goldhaber'in bu saptmaları ışığında, günümüzdeki birçok markanın tüketicileriyle kurduğu bağın niteliklerinin ne olduğunu görebiliriz; Influencer ve/veya Youtuber'larla birlikte çalışmalarını da bu açıdan dikkate alabiliriz.

Sözü edilen aktarılabilme özelliği ekonomiyi hatılatmaktadır. Konuşmacının bütün dinleyicilere tek tek vaadettiği yanıltıcı dikkat ile dikkatin aktarılabilirliğini birlikte düşünmek, Goldhaber'in yeni ekonomi dediği düzeni anlamakta özellikle önemlidir. Bugün insanların hayatına baktığımızda maddi işlemlerden çok daha fazla dikkat temelli işlemler yaptığını görebiliriz. Her gün verilen kararların büyük kısmı, paranın neye yöneleceğinden çok dikkatin nereye yöneleceğiyle ilgilidir artık.

Maddi üretim ve tüketim kapasitemiz asla uyum içinde olamaz. Oransal olarak, bu standart ürünleri üreten kişiler azalırken, kişi başı tüketim artmaya devam etmektedir. Bizi bir zamanlar olduğumuz gibi meşgul edecek miktarda üretim olasıı̆̆ı yoktur artık. Gelişmiş ülkelerde bile tarımdaki Yeşil Devrim besin ürünleri üretiminde çalışan insanların sayısını azaltmıştır örneğin.

Yine de her zamankinden daha meşgulüz. Maddi intiyaçlara dair konfor seviyesi karşılandığı için dikkat ile ilgili konulara, yaşamın anlamı ve anlamsızlığına da merak artmıştır. Bu alanda dikkati sağlamaya dair yükselen bir mücadele hüküm sürmektedir. Bundan ötürü Goldhaber'e göre, "gerçek" dikkat mümkün olmadığından, yanıtıcı dikkat sunan medya araçlarına yönelim artmaktadır.

Burada yazara yöneltilecek bir eleştiri belirmektedir: Gerçek ve yanıltııı dikkat ayrımını neye göre yapabiliriz. Medyaya dikkat ve "gerçek" dikkat ayrımı, yüz yüze iletişime özcü bir anlam yüklemektedir ve medya işin içine girmediğinde iletişimin daha sahici ve otantik olduğu önermesi dile gelmektedir. Bu bağlamda dilbilimde ve psikanalizde geliştirilen gerçek ve sahici olanın bizatihi kendilerinin aslında 
toplumsal olarak inşa edildiği süreci Goldhaber'in görmediğini söyleyebiliriz. Illetişim hep toplumsaldır ve rollere göre biçimlenip şekillenirken, her toplum üyesine de sarih ve sahici olmaktan çok daha başka taleplerle iletişime geçme buyruğu iletilmektedir. Toplumsalın bir sahne ve bu sahnede oynayan "aktörlerin" de her sahne değiştiğinde maskelerini değiştirmek zorunda kalması olgusu, öncelikle de modern toplumsal yaşamın bir özelliği olarak kendisini dayatmaktadır.

Goldhaber, medya ve dikkat konusunu gerçek ve yanıltıcı dikkat ayrımıyla ele aldığında hatalı bir yönde ilerlese de, medyatik dikkatin üretkenlik peşindeki ekonomik bir faaliyetten farklı olduğunun altını çizerken doğru bir tespitte bulunmaktadır.

Goldhaber yüzyüze iletişimde gerçek, sahici ve otantik bir dikkatin olası olduğunu, bunun medyatik iletişimde söz konusu olmadığını işaret etmiş bile olsa, sosyal medyanın kullanıcısına bir özgünlük imkanına sahip kullanıcı olarak da bakmaktadır. Başkasının yaptığını tekrarlayarak dikkat toplamak güç olduğundan Goldhaber'e göre, içinde yaşadığımız dönem sonsuz özgünlük -en azından özgünlük arayışı- dönemi olacaktır. Endüstriyel üretimin tekrara dayalı mantığından tamamen farklıdır bu. Dikkat ekonomisinin sonsuz özgünlük ve çeşitliliğinde endüstriyel ürünlerin değiş tokuşuna dayalı ekonomi geçersiz olacaktır. Dikkatin ölçülebilirliği de o kadar kolay değilir aslında. Piyasa aktörlerinin bu durumda yeni ölçüm mekanizmaları keşfetmek peşinde daha uzun bir süre koşacağı da açıktır. Google Analytics bunun en bilinen örneğidir.

Bu aşamada Goldhaber dikkat ekonomisi ve para arasındaki bağı kurmanın zorunluluğuna değinir. Para, dikkat ile birlikte akar. Ekonomiler arası geçiş dönemlerinde eski servetler yeniyi elinde tutanlara akar. Feodalizmden kapitalizme geçerken aristrokratik soy ve toprak sahipliği paraya dönüşmüştü. Öte yandan yükselen tüccar ve endüstriyel sınıf da eski unvanları satın almış devleti onlara yeni unvanlar vermeye zorlamıştı. Dikkat ekonomisinin yıldızları da paraya kolayca ulaşıyor. Fakat bu akışın karşı istikameti o denli kolay yürümüyor. Para kolayca dikkate çevrilemiyor. Bir konuşmacı açıp sözlügü okusa o dikkate ulaşamaz. Sadece para vererek dikkat elde etmek mümkün değil: illginç olmalı, yanıltıcı dikkat sunabilmeli. Para dikkate akıyor, fakat dikkat kolayca paraya akmıyor.

Buraya kadar akatardığımız dikkat ekonomisi yazınında daha eleştirel kavramsal temeller üzerinden yapılan tartışma Goldhaber'de daha somut ve olgusal örnekler üzerinden kurulmaktadır. Dikkat ekonomisi hakkında söyledikleri şöyle toparlanabilir: Feodal dönemin sonlarına doğru asillği gösteren etkinlikler öncesinde hiç olmadığı kadar şatafatlı bir hale geldi; seremoniler, evlilik törenleri, asil soylara yönelen ilgi arttı; ardından bu ilgi birden işlevini ve önemini yitirdi. Bugün de Forbes 400 listesi kusursuzluğun son noktası gibi görünüyor; fakat bu dekadanlık anlamına geliyor. Para ve fiziksel üretim gittikçe yerini dikkat ekonomisine bırakıyor ve dikkat ekonomisi şu anda, şimdi gerçekleşmektedir. 


\section{Dikkatin Sınırları}

Tiziana Terranova (2012) dikkat ekonomisine dair tartışmaları Jonathan Crary'ye atfen, "dikkatliliğin krizi" bağlamında değerlendirmektedir. Pettman gibi "dikkat"in Internet'e dair teorilerde ekonomik bir kategori olarak kullanılmasının yöntemlerini aramaktadır. Bunu, neoklasik ve anaakım ekonomi teorisini ve güncel kapitalizmde toplumsal işbirliği ve psişik trans-bireyselleşme süreçlerini çözümlemeye çalışarak yapmaktadır.

Dikkat ekonomisi, benzeri teorilere göre enformasyonun merkeziliğine bakışı açısından bir fark içermektedir. Bu açıdan Terranova enformasyonun aşırılığı ve sınırsız imkanlarının karşısına dikkatin kısıtııığını koymaktadır. Algının nörofizyolojisine içkin sınırlara ve tüketim için mümkün olan zamanın toplumsal sınırlarına bu bağlamda işaret etmektedir.

Illk zamanlarında yeni medya ekonomistleri enformasyonun bolluğunu ekonomik Darwinizm'le okuyarak, dijital girişimcinin artı değere sahip olmak için Darwinci rekabet koşullarında hayatta kalma yollarını bulması gerektiğini söylüyorlardı. Terronova ise kısıtlı olan dikkate odaklanarak, organik yaşamın bollukla, yaratıcılıkla yüklü bios'unun yerini yaratıcılıktan ve yenilikçilikten yoksunlaşmış bir organın, beynin aldığı argümanını öne çıkarmaktadır.

Dikkat ekonomisinin teorisyenlerine göre, dikkat kısıtlı ve ölçülebilir, fakat diğerleri gibi bir meta değil, bir çeşit sermayedir. Dikkatin soyut özellikleri ve dijital medyanın "dikkat kümeleri" (attention assemblages) ölçmeyi öne çıkararak (dijital nesnelerin tıklanma, indirme, beğenme, görüntülenme, takip edilme, paylaşılmaları), dikkati piyasalaştırmış ve finansallaştırdır.

Terranova, 1999'da Georg Franck'ın, dikkati “iş dünyasının yeni para birimi" ve yeni bir çeşit sermaye (attentive capital), hatta bir çeşit ücret ya da gelir (ünlülükten gelen bir gelir) olarak tanımladığına işaret eder. Goldhaber bundan dikkat işlemleri (attention transactions), başkaları ise 'dikkat bonoları' kavramlarıyla söz etmiştir. Terranova dikkate dair bu ekonomi teorilerinin genelde ekonomiye dair daha akademik külliyatın kenarında yer aldığına işaret etmektedir. Bunlar yazara göre, genelde internette yayınlanmışlardır, İnternet girişimcilerine hitap etmektedirler, bundan ötürü de kısa ömürlü tartışmalardır. Daha çok, büyük şirketlerin yeni alanlardaki rekabet imkanlarıyla da ilgilidirler (algoritmalar, tıklamalar, görüntülemeler, tag'ler vb.) (2012, s.3).

Terranova dikkatin "kısıtlı" bir kaynak olarak görülmesinin sebebinin sadece sınırlı olmasından değil, aynı zamanda gittikçe değerini yitirmesinden kaynaklandığını savunmaktadır. Herbert Simon'un 1971'de yazdıklarına değinerek, günümüzde de enformasyon bolluğunun bir dikkat sefaleti yarattığının altını çizmektedir. Bu bağlamda, eğer harcanan dikkat tıklamalar ve görüntülemelerle ölçülebiliniyorsa, yitirilen dikkatin de başka bir ölçüm birimine ihtiyacı vardır. Ter- 
ranova beynin uyarıcılara karşı verdiği fizyolojik tepkilerin ölçülmesinden ve beynin nöroplastik potansiyelinin de dikkate alınmasından söz etmektedir.

Bu ölçümler için Carr'ın bir çalışmasına gönderme yaparak; yeni medya objelerine bu denli maruz kalmanın beyinde yeni nöron ağları oluşumuna yol açtığını ileri sürmektedir. Multi-tasking, zengin metin içerikleri vb.'den etkilenen beyinde nöron aktivitesi (akıl yürütme ve uzun dönemli hafızanın yer aldığı) hipokampüs'ten (basit işler ve kısa dönemli hafızanın yer aldığı) prefrontal korteks'e kaymaktadır. Bu bir nevi beyindeki hafıza tiplerinin yeniden şekillendirilmesi, derin düşünce ve anlamadan rutin işlerin hızlı halledilmesine doğru yönelen insanlara dönüştüğümüz anlamına gelmektedir.

Terranova, Catherine Malabou'nun kapitalizmin ruhu ve nörobilimler üzerine yazdığı makalesine atıfla günümüz nörobilimlerinin 'nöral plastisite' kavramını merkezi bir model olarak aldıklarını yazmaktadır: Beyin daha zorlu bilişsel becerilerden feragat ederek rutin işleri olabildiğince hızlı otomasyona bağlayabilmektedir. Bu durumda Terranova'ya göre dikkat ekonomisinde bireyin bilişsel bir kayıp yaşadığı, akıl yürütme, tefekkür ve mahremiyet duygularını kaybettiği kolayca öne sürülebilir. (2011, s. 5 vd)

Beynin sürekli bir işten ötekine hızlıca geçmesinde geçiş maliyetleri de vardır. İşler arttığında bu maliyetler de artmaktadır. Jonathan Crary buna 'dikkatin krizi' demişti, kapitalizmin 19. yy'dan beri algısını (perception) yönetme ve düzenleme peşinde olduğu yeni bir öznenin peşinde olduğunu söylemişti. Terranova dikkat ekonomisi tezlerini Jonathan Crary ile diğer değindiğimiz yazarlar gibi Bernard Stiegler'in kavramlarından yararlanarak tartışır. Dikkat ekonomisi ve dikkat krizine dair iddialar, birlikte düşünüldüğünde dikkati hem kısıtı hem de değerli bir kaynak olarak görülen öznenin dikkat kapasitesinin yeniden şekillendirildiğine ve tükenmiş bir özne üretildiğine işaret etmektedir. Beyin dijital ekonomi için kısıtlı kaynak sunarken, bir yandan da bilişsel kapasitesini yitirmektedir. Bernard Stiegler'in dijital ve ağ yapılı teknolojilerle birlikte 'zihnin yaşamının proleterleşmesi' tezi de zaten dikkati bu olguya çekmiştir. Fakat bilişsellik yoksullaşıyor mu yoksa ikircikli bir öznellik mutasyonu mu gerçekleşiyor, bu nokta henüz tartışma konusu olmayı sürdürmektedir.

Terranova'ya göre, dikkat ekonomisini ilgilendiren bir diğer tartışma da hiper-sosyalleşen beynin olası taklit (imitation) mekanizmaları geliştirip geliştirmeyeceğine dairdir. Dijital medyanın dikkat kümelenmelerine (attentional assemblage) dahil olmak bir yandan okumak, yazmak, izlemek, dinlemek, kopyalamak, yapıştırmak, indirmek, yüklemek, beğenmek, paylaşmak, takip etmek gibi eylemlerle birlikte bir taklit ve sosyalleşmeyi de içermektedir: Düşünceler, duygulanımlar ve algıların toplumsallaşması, üretim ve işbirliğini de gerektirmektedir. (Terranova, 2012, s. 7 vd)

Nörobilimlerde son yıllarda taklit, empati, zihin okuma ve grupların bilişselliği de sıkça tartışımaktadır. Toplumsal bilişsellikte ayna nöronların işlevi ele alındığında, şu anda primat davranışlarıyla kısıtı kalsa da bu çalışmalarda ağ yapı- 
sındaki öznelliklerin, toplumsal bilginin temelde taklit temelli olduğu, taklitin kendine dönük hesaplayan öznenin Donna J. Haraway'in kullandığı bir kavram olan 'stratejik rasyonelliğinin' bir parçası olduğu iddiaları ileri sürülmektedir.

Dikkat ekonomisindeki dikkat ve taklit ilişkisi, nöroplastik beyni sadece yeni medyaya maruz kalan bir mimari olarak değil, aynı zamanda sürekli taklit eylemleri içinde, kendine hakim rasyonel bir ekonomik özne olarak da görmektedir. Bu da toplumsal ağların yayıldığı çevrede dikkat göstermeyi paradoksal bir durumla karşı karşıya bırakmaktadır. Terranova, Lazzarato'nun enformasyon toplumunun 'iş zamanı' ve 'hayat zamanı' şeklinde bir ayrımı yok ettiğine dair post-işçi tezinin yeniden değerlendirilmesi gerektiğine kanaat getirmiştir. Bunu da Lazzarato'nun enformasyon ekonomisinin 'zamansal ve organik/biyolojik süreç olmanın yanı sıra sanal süreçlere de işaret eden yeni bir dirimselcilik getirdiğini öne sürmesiyle bağlantılandırmaktadır. Böylelikle Terranova Lazzarato, Gabriel de Tarde ve Bernard Stiegler'e referanslarıyla internet ekonomisi ve dikkate dair tezlerini geliştirmektedir. Beyin hafızası, dikkat emeği, psiko-sosyal teknolojiler, bunların libidinal enerjiyi tahrip eden yanları üzerinde durmaktadır. Kendisinin esin aldığı düşünür ve yazarlar gibi Terranova da bu gelişmelerin daima olumsuz olmayan, belki yeni kolektif yapılanmalara sebep olabilecek şeyler olduğundan bahsetmektedir.

Dikkat ekonomisinde dikkati ekonomik ve ölçülebilir bir birim olarak görmenin ortaya çıkardığı kavramlar bu durumda şunlardır: Kısıtııık, yoksulluk ve taklit. Dikkatin kısıtlı görülmesi daha çok kurumsal/satıcı perspektifinden bir bakıştır. Dikkat ekonomisine yönelen tartışmalar bu kısıtlılık üzerine yoğunlaştığında, ağ örgütlenmesindeki öznelliğin güçlerine dair fikir üretememektedirler. Daha çok koyun-sürüsü modellerine, kısmi dikkat ve sürekli dikkat dağınıklı̆ı perspektiflerinden bakmaktadıllar.

Stiegler ve Lazzarato gibi ekonomi politik eleştirisi yapan yazarlarsa bu yoksullaşma ve kısıtııığı aşmayı denemektedirler. Dikkatin sadece tekil beynin eforuna işaret etmediğini, kısıtlı ve değiş-tokuş edilebilir bir metaya indirgenemeyeceğini, sürekli yoksullaşma eğilimi göstermediğini dile getirmektedirler. Aksine, dikkatin de öznelliğin teknolojik üretiminden ayrı düşünülemeyeceği ve bu geçişlerde arzuların, inançların ve duygulanımların yeniden icat edileceğini, yayııım göstereceğini ileri sürmektedirler.

Bir yanda dikkat ekonomisini, ticari amaçlarla dikkati organize etme ve yönetmeye dair pratikler söz konusuyken, öte yanda bizim yapmamız gereken de, bu dikkat pratiklerinden farklı öznellik biçimleri ve toplumsal işbirliği modelleri keşfetmek olmalıdır.

\section{Facebook ve Sosyalleşmenin Bedeli}

Thayne (2012) 50-75 milyar dolar değerinde olan ve gelirinin 85\%'ini müşterilerinin hedeflediği kullanıcılara ulaşmalarını sağladığı reklamcılıktan elde eden Facebook ve varlıklarının (kişisel bilgiler, bağlantılar ve tüketim alışkanlıkları içeren 
veritabanı) neden bu kadar değerli olduğunun sebeblerini araştırır. Facebook gelirini, kullanıcılarının kişisel bilgilerini burada paylaşmalarıyla, uygulamanın sağladığı katıımcı ortam ve teknolojik özellikleriyle sağlamaktadır. Thayne, bu açıdan dikkatin edinilmesi ve yönetiminde tasarımsal kararlara dayanılmasının gün geçtikçe küresel kapitalizmin esaslarından biri haline geldiğini söylemektedir. Sosyal ağ servislerinde (SNS, social network sites) kullanıılar sürekli dikkatleri için rekabet eden enformasyon sinyallerine (durum güncellemeleri, süren konuşmalar, resimler, videolar, link'ler, reklamlar) tutunmaktadırlar. Thayne, bu argümanı Herbert Simon'a atıfla ileri sürmektedir; Simon enformasyon bolluğunun dikkat kısıtılığı ürettiğine, enformasyonun dikkati tükettiğine, dikkat yoksullaşmasına yol açtığına işaret etmişti.

Thayne'ın bir başka esin kaynağı medya kuramcısı Jussi Parikka'nın yapıtlarıdır. Parikka öznelliğin 'ağ ekolojileri' (network ecologies) süreci olarak değerlendirilmesi gerektiğini daha 2010'lı yıllarda ileri sürmüştü. Bu çerçevede bilinç temelli bir öznellik tanımına göre, fiziksel ilişkilenmeler ve toplumsallık üzerinden bir öznellik yaklaşımı söz konusuydu. Böylesi ilişkisel bir yaklaşım, SNS'de dikkatin medya izlerkitlelerinin 'gözbebeklerini' dizginlemekten ziyade algoritmik sıralamalara, sosyal ilişkilenimlerin yönlendirilmesine ve organizasyonuna, kullanıcıların ürettiği içeriklere odaklanmaya dayanıyordu. Sibernetik sistem kullanıcılar ve teknoloji arasındaki etkileşimlerle toplumsal öznelliğin üretildiği bir sistemdir. Bu bağlamda Thayne Hardt, Virno, Cote ve Pybus'a atıfla "beğen" tuşunu, duygusal bağlantıların ve ilişkinin üretildiği sosyo-teknolojik bir etkileşim biçimi olarak tanımlamaktadır. Birer özel şirket olarak sosyal ağlar, yaşam biçimlerinden artı değer üretmektedirler. Thayne'ın bu analizi gayrimaddi emek bağlamında bilgi, arzu, dikkat ve toplumsallığın biyopolitik üretimine odaklanan çalışmalara dayanmaktadır.

Thayne argümanlarını üç açıdan ileri sürmektedir: (i) SNS'de öznelliğin toplumsal üretiminin sosyo-teknolojik etkileşimlerle nasıl gerçekleştiğini incelemektedir. (ii) SNS'in ekonomik etkisinde, kapitalist ilişkiler açısından iletişim ve toplumsal etkinlik biçimlerinin nasıl merkezi rol oynadığını sorgulamaktadır. 'Beğen' tuşu bağlamında gayrimaddi emek ve duygulanım teorilerine değinmektedir (iii) Son olarak, dikkati düzenlemek, etkilemek ve yapılandırmak için kullanılan teknik araçlar olan 'Beğen' tuşu ve 'Open Graph' protokolünü incelemektedir. Thayne temelde de asıl Deleuzecü bir kavramsal yaklaşımla kontrol, kipleme ve birey-kaçma (control, modulation and dividuation) gibi biçimlerin Facebook'taki toplumsal aktivitenin ekonomikleştirilmesinde ve nicelleştirilmesindeki rolünü çözümlemektedir. (2012, s. 3)

Thayne iletişim, teknoloji ve kullanımları arasında yeni medya bağlamında yapılan çalışmaların ana izleklerini şöyle özetler: Ağ temelli toplumsalıklar daha geçici ilişkiler, projeden projeye süren ya da fikirlerin hareketliliğine dayalı kısa ömürlü fakat güçlü (insense) karşılaşmalar üretmektedirler. Bunun katılım mimarisi, Web 2.0, katılımcı kültürler gibi çeşitli adlara sahip olduğu, genelde izlerkitleye dair geleneksel fikirlerin dönüştügü iddia edildi. Güncel medya tüketicilerinin basit seyirciler olmadığı, dijital medya ortamındaki katılımcılar oldukları da söylendi. Te- 
peden aşağı, dikey şekilde birden çoka giden (one-to-many), merkezi bir endüstrinin yerini aşağıdan yukarı, çoktan çoka giden (many-to-many), yatay ve eşler arası bir iletişim vaadi tartışması almıştı. Jenkins'in deyimiyle bir yakınsama (convergence) kültürü oluştuğu ve biçimlerin iç içe geçtiği savları yakın tarihli medya ve iletişim çalışmalarının temel savlarına bu şekilde dönüşmüştü.

Thayne, Facebook örneğini bu savların iddialarıyla ele almaya çalıştığında, sosyal iletişim ağlarının popülerliğinin küresel dijital kültürün bir ifadesi olarak da görülmesi gerektiğine odaklanmaktadır. Mark Deuze'ün çevrimiçi katıımcı aktivitelerde doğmakta olan bir değer sistemi ve beklentileri bulmasına dayanarak da, endüstrileşmiş modern toplumlarda gündelik hayatın, farklı ölçülerde bilgisayarlaşmış olmasını yeniden dikkate sunmaktadır. Yükselen bu sibernetik tartışmalar Thayne için önemlidir, zira Facebook tarafından dolayımlanan toplumsal etkileşimler ekranda görünen içeriğin çerçevesinde ve yapılandırmalarında gerçekleşmektedir. Anlamın ve öznelliğin üretiminde insan ve makineden oluşan sosyo-teknolojik ekoloji birlikte işlev görmektedir:

"Kullanıcılar arası etkileşimler, içerik ve teknoloji toplumsal ilişkilerin açık uçlu bir topolojisini yaratıyor: Fikirlerin, inançların ve arzuların performatif ve iletişimsel değiş tokuşuyla. Kullanıcılar etkileşime girdikleri enformasyonlardan ayrı tutulamayacağına göre, ağ toplumlarında paylaşılan içerik sürdüğümüz yaşamlar için kurucu hale geliyor." (Lash 2007; Beer, 2009'dan aktaran Thayne, 2012, s.6)

Bu ortak eylemlilik, değerin, toplumun organizasyonunun ve toplumsal bilginin üretiminde toplumsal bilgi ve teknik operasyonların üretici çokluluğunu kavramsallaştıran Marx'ın genel zeka (general intellect) kavramını hatırlatmaktadır. Facebook örneğinde bu üretim, post-Fordist sermaye döneminde bir kendini-markalaştırma (self-branding) anlamına da gelmektedir. Bu anlamda benlik, öznellik ne bireye ne de kolektife indirgenebilir, ikisinin ortak üretimi söz konusudur. Burada üretim ve yeniden üretim ancak Deleuze'ün meta-üretim (metaproduction) kavramıyla, yani şeylerin değil de iliş̧kilerin üretimi yaklaşımıyla açıklanabilir. Hardt'ın dediği gibi, sermaye tarafından sömürülmeye hazır bir şekilde üretilen kolektif öznellikler çağımızın temel özelliğini oluşturmaktadır.

Sosyal ağ servisleri, kullanıcıların ürettiği içerik ve kişiselleştirilmiş medya içeriğini sergileyen interaktif platformlardır. Bu teknik girişimlerin önemli kültürel ve ekonomik etkileri olmuştur, geçmişte mevcut olmayan iş/gelir modelleri üretilmiştir.

Thayne Facebook'un toplumsal bir fabrika olduğu görüşündedir. Bu bağlamda iletişim toplumsal üretimin, ticari dijital teknolojilerle dolayımlanan yeni bir biçimi haline gelmiştir. Tüketim ve üretim arasındaki sınırlar buldanıklaşmıştır. Thayne Marx'ın Grundrisse'de yazdığı (ve sonradan İtalyan post-işçici geleneğin geliştirdiği) tartışmalarda emek gücünün bireylerin emeği ve vasfılarındansa, 
gittikçe bütün iş gücünün ortak çalışmasına ve genel üretkenliğine dayandığından kapitalist üretim biçiminin fabrikanın kapalı duvarlarının içiyle sınırlandırılamayacağı önermesini yeniden bu açıdan gündeme getirir. Dikkat ekonomisinde de sermayenin alanı toplumun tamamına doğru genişlemiş, ifade biçimleri, yoğun ilişkiler, soyut bilgi gibi birçok iletişimsel eyleme yeni değer biçimlerine dönüşmüştür. Bu aşamada Thayne, Foucault'nun kapitalizmin toplumu bir üretim makinesi gibi kullanmasına işaret eden biyo-iktidar kavramına dayanan Lazzarato'nun dikkat ekonomisinde yeni bir kültürel ve ekonomik dönüşümün gerçekleştiği tezini ele almaktadır. Toplumsal etkinliğin tüm biçimlerine kapitalist imtiyazlar tarafından gayrı maddi emek üzerinden el konulmuştur diyen Thayne, neo-Marksist bir kavram olarak gayrı maddi emeğe, emeğin günden güne makineleştirilmiş, iletişim teknolojileriyle bilgisayarlaştııımış, üretimin tüm aşamalarıyla bütünleşmiş hallerine odaklanmaktadır. (2012, s. 8)

Jason Read'in Marx'ı takip ederek bu gelişmeleri, "gerçek öznelliğin sermaye içinde erimişliği" (subsumption) olarak okumasına işaret eden Thayne, toplumsal ilişkilerin kapitalist değerlemeye göre yeniden şekillendirildiğinin, emeğin kolektif ve teknik koşullarına dair gömülü bilginin üretim sürecine içselleştiğinin ve onunla bütünleştiğinin önemine değinmektedir. Önerdiği üzere, kolektif öznellik Facebook'a içkin olarak ortaya çıkmaktadır. Kullanıcılar ve teknolojinin ortak çalışmasına ve toplumsallaşmasına dayalı etkileşimler, esnek ve gayrı maddi veritabanı yaratımları tüketimin başat yönlerini oluşturmaktadır. $(2012$, s. 9)

Marksist "üretim biçimi" bağlamında düşünürsek, kolektif öznellikler ve kişisel bilgiler dikkat toplayabilmek için üretilmektedir. Üstelik bu üretim serbest zamanda, ücretli emeğin sınırlarının dışında kalan zamanda gerçekleşmektedir. Başka bir deyişle, tarzların, ilgilerin ve arzuların değiş tokuş edildiği iletişimle, tüketim sırasında üretilmektedir.

Geç kapitalist toplumlarda gayrı maddi emeğin yeni bir biçimi söz konusudur: Toplumsallaştırılmış üretim, etkileşim ve duygulanımın temellük edilmesi (appropriation of affect). Duygulanımsal emek burada hisleri, duygusal tepkileri ve arzuları oluşturan ve dolaşıma sokan emek biçimlerini somutlaştırmaktadır. Duygulanım dış uyaranlara verilen bilinçli olmayan, içgüdüsel tepkilerken, duygular bu duygulanımsal tepkilerin sonucunda ortaya çıkan bilişsel kontraksiyonlar anlamına gelmektedir. Burada Thayne Hardt ve Negri'nin Çokluk kitabındaki duygulanımsal emek tartışmalarına referans vermektedir. Bilindiği üzere Hardt ve Negri bu yapıtlarında bu duygulanım mefhumlarının Spinoza'dan geldiğini yazmışlardır. Demek ki diyor Thayne, Facebook profillerinde ve kullanıcı etkileşimlerinde duygulanımsal emeğin ürettiği ve yönettiği kimliği bulabiliriz. Profillerini güncelleyen, ağda etkileşime geçen kullanıcılar kolektif öznellik ürettiminde çalışan duygulanımsal emekçilerdir. Enformasyonlarının kullanım hakkını Facebook'a bırakırlar. Şirketin iş stratejisinde kullanıcı verisinin ve meta-verisinin bir araya getirilmesi merkezi rol oynar, çünkü bu enformasyon ile reklam uygulamalarının kâra dönüştürülmesinin en etkin yolunu oluşturur. 
Bu sapmalardan yola çıkarak Facebook'un çeşitli teknik özelliklerini tartışırken Thayne, toplumsallaştııımış, duygulanımsal öznelliklerin üretiminin sitenin altyapısındaki denetim biçimlerine içkin olduğunu öne sürmektedir. Deleuze'ün Foucault'nun 'disiplin toplumları' kavramından ayrılarak 'denetim toplumları' olarak nitelediği toplumlara dönüştük demektedir Thayne. Yeni bir tahakküm sisteminin ilerleyici ve yaygın kuruluş sürecinin içindeyiz. Dolayısıyla panoptik gözetleme yerini dijital kodla benliğin sürekli kıvrılmasına/bükülmesine bırakır. Her türlü kişisel bilgi kaydedilmekte, izlenmekte ve bir kurumdan diğerine aktarılmaktadır. Elektronik ağ teknolojileri toplumsal denetimin yeni formlarında yoğunlaşmaktadırlar.

Yeni pazarlama teknikleri ise kullanıcıların bilindik anlamda zevk, alışkanlık ve tercihlerinin incelenmesinin çok daha ileri ve yoğunlaşmış yöntemlerini sunmaktadır. Veritabanlarında satın alma, boş zaman, okuma ve iletişim alışkanlıklarına dair ölçülebilir ve ayarlanabilir parametrelerle veri madenciliği yapılmaktadır. Deleuze'ün 'bölünmüş birey' (dividual) kavramı Facebok gibi insan özneyi sonsuz bölünebilir ve indirgenebilir veri temsillerine çevirerek denetim teknolojilerini uygulayan bilgisayar sistemlerini incelerken faydalı olmaktadır. Kişisel verinin sosyal ağ sistemlerine girişi ve Facebook aracılığıyla üretilen bağlantılar özne olmanın biyopolitik süreci olarak görülebilir. Eylemler, sistemin sosyo-teknolojik özellikleriyle denetim altına alınıp düzenlenir. Bu özellikler: Belirli arayüz fonksiyonları (en popüler hikayeler, haber akışı, anlık bildirimler), iletişim araçları (yorum yapma, durum güncelleme ve beğenme biçimleri) ve ticari özellikler (sponsorlu sayfalar, hedefli reklamclık, üçüncü parti uygulamalar) ve Facebook'u oluşturan teknik kod ve algoritmalardır. (Thayne, 2012, s. 12 vd)

Thayne tek tek bu özelliklerin nasıl kullanıcıların deneyimi üzerinde denetim kurduğu ve bireylerin özellikleri bazında nasıl bölündüklerinden, ek olarak da buraya harcanan dikkatten nasıl kâr edildiğinden söz etmektedir. Facebook gibi ağ ekolojilerinde öznelliğin, ilişkisel ve sibernetik bir süreç olarak toplumsal etkinliğin; hem enformasyon makinelerinin hem de kullanıcıların sağladığı verinin birlikte rol almasıyla gerçekleştiğine işaret etmektedir. Sosyal ağ servisleri yeni bir dağıtık estetik ile toplumsallaştırılmış öznellikler üretmektedir. Medya izlerkitlesi için iş ve eğlence arasındaki ayrımları bulanıklaştırmaktadır. Facebook'ta dolayımlanan toplumsal etkileşimler bir çeşit gayri maddi emek olarak görülebilir, çünkü şirket dikkati kipleyen ve düzenleyen dijital teknolojilerle ekonomik değer üretimi sağlamaktadır. Kullanıcıların bıraktıkları dijital izler işlenip dönüştürülerek daha fazla toplumsal etkileşim tetiklenmektedir. Servislerin işe koştukları teknik özellikler kullanıcıların ilgileri, beğenileri ve hoşlanmadıkları şeylere dair değerli bilgileri nicelleştirmektedir. Bu sayede kullanıcılarla ticari şirketler arasında bağlar kurulmaktadır. Thayne'e göre dikkat ekonomisi, Facebook'un üretim biçimleri kullanıcılar tarafından üretilen bilginin kiplendiği ve iktisadileştirildiği, verinin geri beslemesiyle hedefli pazarlama kampanyalarının uygulanabildiği sibernetik bir sistemi temsil etmektedir. 


\section{Sosyal Medyanın Finansallaşması}

Greg Elmer 2018 yılında dikkat ekonomisinin sınırları bağlamında Facebook örneği üzerinden yaptığı tartışmada, Facebook'un mevcut gelir kaynaklarının "dikkat ekonomisi" çerçevesinde yapılan tanımlamaların ötesine uzandığını öne sürer. Facebook'un gelir kaynaklarının kullanıcıların ürettiği değerle sınırlı olmadığı görüşündedir ve bu görüşünü de sosyal medyanın finansallaşma ile ilişkisi üzerinden kurmaktadır.

Elmer, Facebook'un (FB) NASDAQ'a arzı öncesi ve sonrası gelir kaynaklarını karşılaştırmasında, 2009'da \% 98'i reklam satışlarından, yani aslında kullanıcı "dikkati" üzerinden elde edilen gelirlerin, NASDAQ sonrası başka gelir kaynaklarının da devreye alınmasıyla \%82'ye düştügünü bulgular. Elmer, bu bulgudan hareketle, borsada işlem görmeye başlamasının Facebook'un hem farklı gelir kaynaklarının peşine düşmeye hem de finansallaşmış bir şirket olarak yeniden yapılanmaya yönelttiğinin altını çizmektedir.

Elmer, Facebook'un ekonomik değerini dair tartışmasını sosyal medya ve emek konusundaki çalışmaların öncü ismi Chritian Fuchs'a atıfla yapmaktadır. Fuchs'a dayanarak Elmer, Facebook'un finansal değerinin kullanıcıları tarafından üretilen artık değere dayandığı savını doğru ama yetersiz bulmaktadır; çünkü şirketin topladığı ve ürettiği verilere (big social data) dayalı spekülatif ve potansiyel değer üretimini tanımlayabilmekte ve tartışabilmekte başarısızlığa mahkum olunduğu görüşündedir. Değeri gelecekteki finansal beklentilere göre değişim gösteren (perceived future financial prospect) Facebook'un söz konusu finansallaşmış mantığını yansıtacak bir arayış içindedir.

Bunun için de ilginin aşağıdaki boyutlara yöneltilmesini önermektedir: Facebook'un büyük sosyal veri konusundaki ayrımcı uygulamalarını, kullandığı sosyal ağlandırma (social networking) yönteminin zararlarının sadece kullanıcıların verileri ve zamanlarının veri madenciliğiyle sınırlı olmadığını göstermek gerekir; büyük sosyal verinin finansallaşma eleştirisi, "dikkat ekonomisi" hakkındaki büyük sosyal veriye ${ }^{1}$ dönük tartışmaların Facebook'un ayrımcı veri pratiklerini ne kadar karşılayabildiğinin sorgulanmasıyla mümkündür. Facebook'un değeri Elmer'e göre biraz burada yatmaktadır. Algoritmaların ürettikleri bağlantıların ne biçimlerde kullanılabileceğinin bugünden kestirilemeyişi, şirketin değerlemesini spekülasyona oldukça açık hale getirmektedir.

1 Elmer'e göre değeri yaratan şey veriler kadar, belki daha fazla veriler arası ilişkileri kurmaya çalışan algoritmalardır. Burada Karl Palmas'ın fabrika yerine önerdiği laboratuvar metaforuna atıfta bulunmaktadır. Palmas, Deleuze'ün Panoptikon yorumlamasını takip ederek, günümüz şirketlerinin veri setleri ve noktaları arasında sürekli bir ilişki arayışında olduğunu belirtmiştir. Panoptikon'u bir adım geliştirerek Panspectron diye yeni bir kavram tanımlamış, laboratuvara, mikroskopa, gözle görülemeyene referansla şöyle demektedir: "Elektromanyetik spektrumu daha geniş bir frekans segmenti izler. Başka bir deyişle, panspektron yalnızca insan gözüyle görülebilenleri değil, aynı zamanda radyo, radar, mikrodalgalar ve benzerlerini de kaydeder." (2018, s. 6) 


\section{Bakış ile Göz Atmak Arasındaki Fark}

Zulli (2017) dünyayı algılamanın yeni bir biçimi olarak 'bakış' (gaze) karşısında 'göz atma' (glance) pratiğinin yükselişini ve bu geçişin etkilerini irdeler. Göz atma, dikkat ekonomisinin temel özelliklerinden biridir. Zulli bunu üç başlıkta açımlar: Sosyal medya uygulaması olarak Instagram'da (i) göz atma eylemi uygulamanın adında ve arayüz tasarımında içerilmektedir, (ii) göz atma vurgusu, kullanıcıları belli bir davranışa, yani kullanıcı davranışına yönlendirmektir, (iii) göz atma sosyal ve ekonomik sermayenin bir öncülü olarak işlemektedir. Göz atmanın yeniden kavramsallaştırııması, bu eylemin dikkat ekonomisi bağlamında toplumsal ve ekonomik davranışı dönüştüren baskın bir görme kipi olarak önemini ortaya koymaktadır.

Zulli'nin ilk argümanı görsellik ve görme biçimlerinin felsefenin temel konuları arasında olduğudur. Görselliğin ana kavramı genelde bakıştır (gaze). Bakış sürekli, sabitlenmiş, uzun süren bir görme eylemidir. Bu görme literatürünün öte yanındaysa, göz atma (glance) bulunur; göz atmayı bakışın anti tezi olarak görebiliriz. Algıyı bir nesneye ya da özneye sabitlemez, çabuk, geçici ve gelişigüzelliğiyle bakıştaki egemenliği görsel bir özgürlükle değiştirir.

Zulli böylesi bir göz atma kavramsallaştırmasıyla, profesyonel ve kişişel hedefler için dikkatin en değerli meta haline geldiği dikkat ekonomisinde, göz atmanın temel bir rolü olduğunu iddia etmektedir. Zulli'ye göre, dijital teknolojilerin kullanıcıların davranışlarını ve ekonomik davranışı nasıl yeniden yapılandırdığını anlamak için "göz atma" kullanışlı bir kavramdır Çünkü sosyal medya uygulamaları, arayüzlerini göz atmayı birincil görme biçimi olarak ele alarak tasarlamaktadır. Göz atmanın bu şirketlerin ekonomik modellerindeki yerini incelemek için bu yüzden önemlidir. Sonuç olarak, dijital ekonomide bu platformların bu tercihleri toplumsal ve ekonomik davranış üzerinde etkili olmaktadır.

Çeşitli düşünürlerin bakış ve göz atma üzerine yazdıklarından bir literatür taraması yapan Zulli, bakışta süre, harcanan zaman ve telaşsızığın söz konusu olduğunun altını çizerek, bakışın bireye veya nesneye yöneltilen, kalan imajları dışlayan bir yanı olduğuna işaret etmektedir. Önceden karar verilmiş ve kapalı bir görme biçimidir söz konusu olan. Zulli Sartre'a dayanarak, bu bakış kavrayışının ötekini yabancılaştırdığını ve nesneleştirdiğini öne sürmektedir. Lacan'a dayanarak da bu bakış kavrayışının bakılana mesafelenip onu nesneleştirerek öznelliği yeniden tanımladığını söylemektedir. Bu nesneleştirme tartışmaları ise tarihsel, kültürel ve politik normların içine gömülüdür ve iktidar ilişkilerini temsil etmektedir. Buna örnek olarak Zulli, Mulvey'in sinemadaki dikiz ve fetiş üzerine yazdıklarını, veFoucault'nun gözetleme ve denetim aracılığıyla sabitlenen bakış çözümlemesini vermektedir. Bu bağlamda göz atmanın çok daha hafif bir külliyatı olduğuna işaret ederek, Casey'nin göz atmayı bakışın hegemonik denetiminden özgürleşmiş bir eylem olarak görmesini önemsediğini yazmaktadır. Çünklü bakıştan farklı olarak göz atmada bakan ve bakılan ilişkisi daha gevşektir, tüm bireyler teorik olarak 
aktif ve katılımcıdırlar. Göz atmada derinlik yerine yüzeyler önemlidir. Köşeler ve sınırlar yerine hareket halinde ve yayılan yüzeyler vardır. (2017, s. 2 vd)

Bu savlardan hareket eden Zulli, dikkatin, günümüz kapitalizminde önemli bir kaynak olduğunun uzun süredir tartışıldığının, bu konuda mutabık olunduğunun altını çizer. Örneğin, Dallas Smythe 1977 yılında televizyon izlerkitlesinin ekonomik bir etkinlik içinde olduğunu, burada biriktirilen metaların reklamcılara satıldığını yazmıştı. Bu anlamda aracılı bir içeriğe erişim bir sermaye işletmesidir. Öte yandan televizyon izlemek tamamen pasif ve sömürülen bir emeğe işaret ederken, günümüzde hem üretici hem tüketici olan kullanıcı (produser) içeriğin üretiminde fail olarak yer almaktadır denilir. Bu aktif katılım konusu, dikkatin ölçümüne dair metriklerin medya ortamına göre değişmesi kriterlerine göre biçimlenmektedir. Tıklama başı maliyetler (click-through rates) uzun süre kullanılmıştır, şimdilerde de duygulanımsal ilişkiler ve kullanıcıların beğeni, retweet sayıları gibi parametreler reklamın ücreti için kullanılmaya başlanmıştır. Dijital ortamda değer basitçe gözbebeklerine erişim süresinden ziyade etkileme, katılım, nüfuz alanı, liyakat, deneyim hatta tutku gibi kavramlarla ölçülür hale gelmiştir.

Oysa Zulli'ye göre ölçüm biçiminden bağımsız olarak, dikkat somut ve kısıtlı bir metadır. Dikkat arzusu ise bireysel ve organizasyonel davranışı yeniden yapılandırmaktadır: İnteraktif içerikte artma, değişen yayınlama alışkanlıkları, çevrimiçi platformların daha stratejik kullanımları vb söz konusudur. Bir vaka olarak Instagram'ı incelersek diyor Zulli, dikkat ekonomisinin, 'göz atma'yı bir yönelmeden ziyade baskın, arzulanır ve kârlı bir görme biçimine nasıl dönüştürdügünü anlayabiliriz. (2017, s. 4) Dikkat ekonomisinde göz atmanın baskın konumunu Zulli, Instagram'ın tasarımsal ve arayüzsel özelliklerini, bunların tasarlayıcı kurumlar tarafından kullanıcıları nasıl yapılandırmaya çalıştığını inceleyerek açar; burada "platform çalışmaları" yaklaşımına dayanır.

Zulli Instagram konusunda şu tespitleri yapar: Adı en başından şipşak, çabuk ve uçuculuğu hatırlatır. Amacı hızlı ve verimli olmaktır. Hızlı bir döngüde çok çeşitli imajlara göz atma fırsatı verir. Ana sayfasında tek resim görünmesine rağmen, aşağı sürükleyerek sonsuz resme ulaşılabilir. Arama yapıldığında çıkan resimler ise çok daha küçüktür, yine sonsuz aşağı sürükleme imkanı vermekle birlikte mevcut ekranda göz atmaya da olanak sağlar. Göz atmaya uygunlukları aynı zamanda küçüklükleri ve taşınabilirlikleriyle kuvvetlenir. 24 saat boyunca yayında olup sonradan silinen canlı yayınlar göz atmanın uçuculuk hissini hatırlatır. Bu canlı yayın seçeneği kullanıcılar arası etkileşimi arttırarak daha aktif ve sürekli göz atma eğilimini destekler. Instagram'da hiçbir sayfanın dibi ya da sonu yoktur. Teorik olarak, kullanıcıları uygulama ekranını "sonsuza dek" aşağı sürükleyebilirler. Tasarım sadece kullanıcıların resimleri nasıl görüntülediğini değil, nasıl resim yüklediklerini de yapılandırır, işlemsel göz atma eylemine katkı sağlar. Instagram'ın teknik özellikleri ve sosyal yapısı kullanıcılarını üç şekilde koşullar: Paylaşımların tipi, zamanı ve kendini markalama. Uygulamanın sunduğu filtreler resimlere uygulandığında onlara bir sanatsal değer kazandııır. Bu filtreler yüksek teknolojili akıllı telefon kameralarıyla birleştiğin- 
de profesyonel görünen fotoğraflar ortaya çıkar. Böylesi fotoğraflara ulaşabilme yetisi, yaşamı "buradan iyi bir Instagram fotoğrafı çıkar mı" (2017, s. 7 vd) sorusunda somutluk kazanan şeyi deneyimlemeye yöneltir.

Dikkat toplayabilmenin bir yolu doğru zamanda ve düzenli olarak paylaşım yapmaktan geçtiğinden kişilerin paylaşım yapma sıklıkları platformun katkısıyla düzenlenir. Bireyin kendi yaşamına uyguladığı pazarlama teknikleri dizisi anlamına gelen kendini markalamayla benlik satılabilir bir meta olarak düşünülmeye başlanır. Instagram uzmanları kullanıcılara hesaplarını bir tema etrafında örgütlemeleri yönünde çağrıda bulunur: Yemeksever, dünya gezgini, fitness gurusu, hayvansever, ironik hipster vb. Marka ne kadar tutarlıysa izleyiciler o kadar uzun süre göz atar. Sanatsalık, zamanlama ve kendini markalama pratikleri işlemsel göz atma ya da çok-yönlü bakış değiş tokuşuna katkı sağlar. Bir resim ilgi çektikten sonra diğer fotoğraflara bakıır, yorum yazılır, profil incelenir, marka ile daha yakın bir ilişki kurulur. Geleceğe dair de bir bağ oluşturulur. Bu süreç kendini tekrar eder. Kullanıcılar stratejik olarak topladıkları ve verdikleri dikkati yapılandırarak daha kapsayıcı bir Instagram ağına hizmet ederler. Bu işlemsel göz atma, diğer bazı görme biçimlerindeki hiyerarşik güç ilişkilerini düzleştirir. Bakışta (gaze) sabit, belirlenmiş ve kapalı olan ve bakılanı nesneleştiren ilişki yerine bakılmak istenen kullanıcılar ortaya çıkar. Karşııklı göz atma pratikleri sebebiyle katı bir hiyerarşinin yerini daha esnek bir ilişki alır. (2017, s. 8 vd)

İşlemsel göz atma pratiğinden -bakmaktan ve bakılmaktan- gelir sağlamanın da çeşitli yolları vardır. Sosyal sermaye sanatsallık ve markalamayla bağları güçIendirip geliştirmek için bilinçli ve bilinçsiz çabaların sonucunda biriktirilir. Sosyal sermayeyi arttırmak ve sürdürmek amacıyla zaman, enerji ve para yatıımı yapıır, karşılığındaysa onaylanma, tanınma, sosyal hareketlilik ve finansal kârlılık sağlanır. Sürekli kullanım sonucunda sıradan kullanıcılar "influencer" ya da mikro-ünlüler haline gelir, niş bir gruba hitap etmeyi başarırlar. Instagram'da neredeyse daima göz atma ve sosyal sermaye ekonomik sermayeyi önceler. Illki biriktiğinde marka ve kullanıcı işbirlikleriyle, kullanıcılar kazandıkları göz atma miktarını kurumlara çeşitli şekillerde pazarlarlar. Instagram kullanıcıları dikkatin toplumsal tanınma, reklam olanakları ve potansiyel gelir anlamına geldiğini bilir. Bu sermaye beklentisi dikkat-arayıcı davranışlarla ve uygulamayla etkileşimi artııır. Kullanıcıların bir kısmı kâr edebildiği sürece herkes kâr etme olasılığını düşünebilir hale gelir. Dolayısıyla Zulli açısından, dikkatin bu denli önemli bir meta haline geldiği bir dönemde Instagram'ın göz atmayı nasıl öne çıkardığı ve kolaylaştırdığını kuramsallaştırmak önemlidir. Zulli bunu, dijital ekonomide emek sömürüsü tartışmalarını tekrardan ele almak için Instagram'ın uyguladığı haliyle göz atma üzerine düşünmenin gerekliliğini vurgulama açısından önemsemektedir. (2017, s.9 vd)

Etkileşimli teknolojilerin sosyal medya sitelerinin kullanıcı tarafından üretilen içeriğe karşılığını vermemesiyle emek sömürüsüne katkı sunması, Instagram için de söz konusudur. Ancak Zulli'ye göre Instagram, tasarımsal olarak dijital olmayan mesleklerdeki emek/sermaye döngüsüyle uyumludur. Instagram kulla- 
nıcılarının dijital ekonomiye reel anlamda çalışarak değil, katıımları sayesinde kazanç sağladıklarının altını çizmektedir.

Özetle Zulli dikkat ekonomisinde göz atmanın bakışı gölgede bıraktığını öne sürer. Bakıştaki dikizcilik ve fetişizm elbette göz atmada da hâlâ vardır, fakat bu sefer bakılan kişi durumun farkındadır. Bu sebeple bakıştaki güç dengesizliği göz atmada bulunmaz. Bakılmak bu sefer sadece beklenen bir şey değil, istenen bir eylem haline gelir, sermaye birikimini sağlar.

\section{Sonuç: Dikkat Değil Verimlilik Ekonomisi Mi?}

Dikkat ekonomisine "kavramsal" yaklaşan düşünürlerin ve yazarların çağımıza dair tanılarını ele aldığımız bu yazıda, bir video söyleşisi kaydıyla sektör temsilcilerinin aynı konuda ne düşündügüne işaret etmenin de gelecekteki çalışmalara yön verebileceğini düşündük. Attention Economy to Efficiency Economy başlıklı video kaydında², bir teknoloji platformu editörü Dan Costa dijital ajans CEO'su Aaron Shapiro ile söyleşi yapıyor. 2018 yılında sektörün içinden yapılan bu tartışma, gelecek için akademik araştırmalara bir perspektif sağlayabilir. Bu video dikkat ekonomisinin sonunun geldiğini duyurmaktadır. Aaron Shapiro şu saptamaları dile getirmektedir:

"20 yıldır sektör dikkat üzerine kuruluydu. sonrasında bunun aşırılıklarıyla karşılaştık. Sahte haberler ve bağımlılık tartışmaları başladı. Bu alandan da benim "efficiency economy" dediğim yeni bir model çıktı. Bu tüketiciyle çok daha doğrudan ilişkiye geçen bir model. Insanlar kullandıkları şeyler için para ödüyorlar. Aldıkları verimlilik ve hizmet için para ödüyorlar. Internetten gelir elde etmeye dair yeni bir modeldir bu. Eğer para kazanmanın yolu daha fazla dikkate ulaşabilmek ise, içerik üretiminde bunun karşılığı sansasyonel olanı gerçeğe yeğlemek, eğlence sektöründeyse bağımlılık yaratacak ürünler geliştirmek. Pazarlama dilinde buna "oyunlaştırma" diyorlar. Bunun anlamı aslında insanların enformasyonu işleme ve davranış biçimlerine müdahale etmektir. Rasyonel olarak kullanmayacakları denli çok ürünü kullanmalarını sağlamaktır. İnternet ekonomisinin büyük kısmı bu mekanizmalarla dönüyor."

Shapiro tekno optimist olduğunu söylemektedir. Dikkat ekonomisinin bu denli aşırı noktalara geleceğinin beklenmediğine işaret ederek, toplumun kendini düzelttiğini haber vermektedir. Şirketlerin de böyle yaptığının altını çizen Shapiro şöyle devam ediyor:

"Facebook kişisel bilgileri saklama konusunda geri adım attı. Birçok internet firması internette para kazanmanın yolları açısından temellere dönecek. Teknolojinin birincil amacını hatırlayacak: Bir şeyleri daha kolay, basitçe ve verimli yapmak. Uber örneğindeki gibi".

2 Bkz., https://www.youtube.com/watch?v=MlwZDwxuChU 
Bu kaydın da gösterdiği gibi konunun önemi ortadadır. Kuramsal tartışmalar, yaşadığımız çağın tüketim çağı olduğunu, bunun da dikkatin ekonomikleşmesini beraberinde getirdiğini Marksist ve Post-marksist yazına başvurarak, eski ama görünüm ve biçim değiştirmiş olguları yeniden kavramsal bir aura ile donatarak tanıtlamaya çalışmaktadırlar. Jonathan Crary çağımııın tüketimci ve finansal kapitalizminin insanın elinden uyku gibi doğal bir ihtiyacın bile alınmasını kolaylaştıracak bir arayışta olduğunun altını çizerken, özel zamanın tahakküm altına alındığını belirtmektedir. Crary'den daha Marksist bir yerden dikkat ekonomisi olgusunu değerlendiren Goldhaber, yeni bir doğal ekonomi kavrayışı için dikkat ekonomisi tartışmalarına odaklanıyor ve, emeğin maruz kaldığı yeni sömürü biçimleri ile dikkat ekonomisi arasındaki bağlantıları kuruyor. Yeni bir çağda olduğumuzun altını Marksist kavramları yeniden ele alarak çiziyor. Dikkatin sınırlılıkları olduğunu düşünen Terranova bilişsel kapitalizm çağında insanın zihinsel, beyinsel ve kişisel tarihine nasıl el konulduğunu açıkça gösteriyor. Facebook'un sadece dikkatin hapsedildiği bir yer değil aynı zamanda tüm toplumsal, politik ve kültürel kodlarımızı dönüştüren bir medya teknolojisi olduğuna Thayne ve Elmer değiniyor. Dikkatin kıt meta olduğunun altını çiziyorlar. Zulli bakışın değil de ritmik bir göz atmanın sosyal medya kullanımıyla yaygınlaşmasının yol açtı̆̆ı yeni medya tüketim biçimlerine dikkati çekiyor. Sonuç olarak, yeni bir ekonomik, toplumsal, simgesel ve duygusal dünyada yaşamaya başladığımız açıkça görülüyor.

Burada dikkati en çok çeken olgu, medya ve iletişim çalışmalarında öncelikli olarak felsefe ve iktisat, ardından da psikoloji ve teknolojiye dair başka alanlarla üretilmiş kavramların, alanımızın kuramsal ve düşünsel kendi içine sıkışmışlığına ve liberal "sözde bilimsel" açıklama biçimlerine alternatif oluşturmalarıdır. Bu alternatif kavramsal araçlar alanımızda göz ardı edildiğinde, insana ait hemen tüm alanların dikkati meta ve sermaye olarak daha üretken kullanmak isteyenlerin denetimi altına girdiğini görmek, insanın bu denetimden kaçacak yollarının olduğunu bilmek imkansız hale gelmektedir. Üstelik aktardığımız video kaydında görüldüğü üzere piyasa aktörleri bile teknolojik imkanların aşırıya kaçan kötüye kullanımının farkına varmıştır; daha reel ve ortak yararı gözeten kullanımların araştırıması gerektiğinin bilincine varmışlardır. Bu bilinçlenmenin iletişim alanında egemen olan tekniğin mistifikasyonundan yana olan araştırmacılara da taklit yoluyla bulaşması önemli ve gereklidir. 


\section{Kaynakça}

Agamben, G. (2013). Kutsal İnsan. Çev. İsmail Türkmen, İstanbul: Ayrıntı Yayınları. Agamben, G. (2018). İstisna Hali. Çev. Kemal Atakay, İstanbul: Ayrıntı Yayınları. Baudrillard, J. (2020). Tüketim Toplumu. Çev. Nilgün Tutal\&Ferda Keskin, İstanbul: Ayrıntı Yayınları.

Baudrillard, J. (2013). Amerika. Çev. Yaşar Avunç, İstanbul: Ayrıntı Yayınları.

Bucher, T. (2012). A Technicity of Attention: How Software 'Makes Sense'. Culture Machine, 13. 3 .1. 2020 tarihinde https://culturemachine.net/wp-content/ uploads/2019/01/470-993-1-PB.pdf adresinden alındı.

Crary, J. (2015). 7/24: Geç Kapitalizm ve Uykuların Sonu. Çev. Nedim Çatlı, İstanbul: Metis Yayınları.

Elmer, G. (2018). Prospecting Facebook: the limits of the economy of attention. Media, Culture \& Society, 00(0), 1-15.

Goldhaber, M. (1997). The attention economy and the Net. First Monday, 2(4). 3 1, 2020 tarihinde https://firstmonday.org/ojs/index.php/fm/article/view/519/440 adresinden alındı

Pettman, D. (2017). Sonsuz Dikkat Dağınıklığı: Gündelik Yaşamda Sosyal Medyaya Odaklanmak. Çev. Yunus Çetiner, İstanbul: Sel Yayıncılık.

Terranova, T. (2012). Attention, Economy and the Brain. Culture Machine, 13. 3 1, 2020 tarihinde https://culturemachine.net/wp-content/uploads/2019/01/465-973-1-PB.pdf adresinden alındı

Thayne, M. (2012). Friends Like Mine: The Production of Socialised Subjectivity in the Attention Economy. Culture Machine, 13. 3 1, 2020 tarihinde https:// culturemachine.net/wp-content/uploads/2019/01/471-1021-1-PB.pdf adresinden alındı

Zulli, D. (2017). Capitalizing on the look: insights into the glance, attention economy, and Instagram. Critical Studies in Media Communication, 1-14. 